\title{
Methane seepage at Vestnesa Ridge (NW Svalbard) since the Last Glacial Maximum
}

\author{
Schneider A. ${ }^{1,{ }^{*}}$, Panieri G. ${ }^{1}$, Lepland A. ${ }^{1,2,8}$, Consolaro C. ${ }^{1,3}$, Cremiere A. ${ }_{1,2}^{2,4}$, Forwick M. ${ }^{5}$, \\ Johnson J. E. ${ }^{6}$, Plaza-Faverola A. ', Sauer S. ${ }^{1,2,7}$, Knies J. ${ }^{1,2}$
}

${ }^{1}$ UiT Arctic Univ Norway, Dept Geosci, CAGE Ctr Arctic Gas Hydrate Environm \& Climate, N-9037

Tromso, Norway.

${ }^{2}$ Geol Survey Norway, N-7491 Trondheim, Norway.

3 Plymouth Univ, Sch Geog Earth \& Environm Sci, Plymouth PL4 8AA, Devon, England.

${ }^{4}$ CALTECH, Div Geol \& Planetary Sci, Pasadena, CA 91125 USA.

${ }^{5}$ UiT Arctic Univ Norway, Dept Geosci, N-9037 Tromso, Norway.

${ }_{7}^{6}$ Univ New Hampshire, Dept Earth Sci, Durham, NH 03824 USA.

${ }^{7}$ Inst Francais Rech Exploitat Mer Ifremer, Dept Marine Geosci, Plouzane, France.

8 Tallinn Univ Technol, Dept Geol, Tallinn, Estonia.

* Corresponding author : A. Schneider, email address : andrea.schneider@uit.no

\begin{abstract}
:
Multiple proxies in the geological record offshore NW Svalbard track shallow subseafloor diagenesis and seafloor methane seepage during the Last Glacial Maximum (LGM) extent and the disintegration of the Svalbard Barents Sea Ice Sheet (SBIS). Vestnesa Ridge, located at $79^{\circ} \mathrm{N}$ and in $1200 \mathrm{~m}$ water depth, is one of the northernmost known active methane seep sites and is characterised by a subseafloor fluid flow system, numerous seafloor pockmarks and gas flares in the water column. In this study, we develop a Late Pleistocene and Holocene stratigraphic framework, use stable oxygen and carbon isotope signatures $(\delta 180, \delta 13 \mathrm{C})$ of benthic and planktic foraminifera, the mineralogical and carbon isotope composition of methane-derived authigenic carbonate (MDAC) and sediment geochemical data of ten sediment cores to assess methane seepage variability on Vestnesa Ridge.
\end{abstract}

The studied cores cover the age range between 31.9 and $10 \mathrm{cal}$ ka BP and record 32 negative $\delta 13 \mathrm{C}$ excursions in benthic and planktic foraminifera with amplitudes down to $-29 \%$ VPDB. These $\delta 13 C$ excursions are often associated with elevated $\mathrm{Ca} / \mathrm{Ti}$ and $\mathrm{Sr} / \mathrm{Ti}$ elemental ratios in sediments and MDAC nodules. The precipitation of MDAC overgrowth on foraminiferal tests explains most of the negative $\delta 13 \mathrm{C}$ excursions. In this dataset, the oldest recorded methane emission episodes on Vestnesa Ridge occurred between the LGM (24-23.5 cal ka BP) and Heinrich Event 1 (HE 1; 17.7-16.8 cal ka BP).

Geological indicators for past subseafloor methane cycling and seafloor methane seepage, such as negative foraminiferal $\delta 13 \mathrm{C}$ excursions, MDAC nodules, and elevated $\mathrm{Sr} / \mathrm{Ti}$ elemental ratios recorded in post-LGM sediments, possibly represent vertical migration of the sulphate-methane transition zone (SMTZ) and post-date sedimentation by up to $13.4 \mathrm{ka}$. However, it is important to note that indications of post-LGM seafloor methane seepage at Vestnesa Ridge also correspond to the established methane 
efflux chronology for the adjacent Barents Sea shelf, implying that glacio-isostatic adjustments and associated re-activation of pre-existing deep-seated faults after disintegration of the SBIS are likely important controlling factors on fluid migration towards the seafloor.

\section{Highlights}

- Multiple proxies document diagenesis and methane seepage at Vestnesa Ridge since the LGM. Diagenetic alteration of foraminifera and MDAC precipitation may postdate the host sediment age by up to $13.4 \mathrm{ka}$. Timing of methane seepage corresponds to the LGM and deglaciation of the SBIS. Glacio-isostatic adjustments may be a key control on methane seepage.

Keywords : Micropaleontology, Foraminifers, Stable isotopes, Methane seepage, Authigenic carbonate, Holocene, Pleistocene, Paleogeography, Deglaciation, Arctic Ocean 
60 Current global warming raises concern about the role of methane, a powerful greenhouse gas, in the

61 Arctic as the circum-Arctic is expected to experience a larger temperature increase than any other

62 region on the planet (Serreze and Barry, 2011; IPCC, 2013; AMAP, 2015). In the upcoming century,

63 increasing Arctic bottom water temperatures are hypothesised as potential drivers for destabilisation

64 of gas hydrates along continental margins that may cause unprecedented release of methane into the

65 water column and the atmosphere (Reagan and Moridis 2007; Westbrook et al., 2009; Biastoch et al.,

66 2011; Giustiniani et al., 2013; Kretschmer et al., 2015; James et al., 2016). Although causal relationships

67 between recent climate warming and increased methane release from Arctic Ocean sediments may

68 seem likely, seepage observed today could have been initiated thousands of years ago. For example,

69 methane release on the East Siberian Arctic Shelf attributed to current global warming (Shakhova et

70 al., 2010) is more likely the result of submarine permafrost thaw after the inundation of terrestrial 
permafrost during the Holocene marine transgression (Bauch et al. 2001; Dmitrenko et al., 2011). Also, the persistent leakage of methane in the deep ocean offshore north-western Svalbard may not be related to climate warming (Knies et al., 2018).

To evaluate if climate warming or other Earth system processes affect the release of methane stored in Arctic Ocean sediments, a better understanding of the timing and drivers of past methane seepage variability in the Arctic is required. Since active methane seepage at Vestnesa Ridge, western Svalbard (Fig. 1), was first revealed by water column acoustic data, research in the area has provided key information for understanding the dynamics of seafloor methane release and seepage over geological time scales in the Arctic (Panieri et al. 2017b and references therein). Previous studies found evidence for seepage occurring during the past 17 cal ka (Panieri et al., 2014; Consolaro et al., 2015; Ambrose et al., 2015; Sztybor and Rasmussen, 2017a; 2017b; Schneider et al., 2017). However, these observations have limited regional coverage. The objective of this study is to identify episodes of past methane seepage along Vestnesa Ridge since the Last Glacial Maximum (LGM) and during the retreat of the Svalbard-Barents Sea Ice Sheet (SBIS). We develop a Late Pleistocene and Holocene stratigraphic framework for the investigated sediment cores from Vestnesa Ridge, and correlate our sedimentary record with established stratigraphic marker horizons along the western Svalbard continental margin. We use multiple proxies such as $\delta^{18} \mathrm{O}$ and $\delta^{13} \mathrm{C}$ records from benthic and planktic foraminifera, chemosynthetic bivalves, mineralogy and $\delta^{13} \mathrm{C}$ of MDAC, and sediment geochemical data to identify shallow subseafloor diagenesis and seafloor methane seepage. This study provides the first comprehensive insight into timing and drivers of methane seepage activity or quiescence along Vestnesa Ridge since the LGM.

\section{$2 \quad$ Background and processes in gas-charged sediments}

Methane $\left(\mathrm{CH}_{4}\right)$ can be of microbial, thermogenic, or abiotic origin (Whiticar, 1999) and occurs in hydrocarbon reservoirs, stored in hydrate, or as dissolved and free gas in continental margin sediments worldwide (Kretschmer et al., 2015; Ruppel and Kessler, 2017). Methane seepage occurs where fluids 
enriched in methane migrate toward the sediment-water interface (e.g. Torres and Bohrmann, 2006; Etiope, 2015). Seepage is commonly understood as the release of fluids from the seafloor on continental margins and its location is named "seep" (Judd and Hovland, 2007 and references therein). The geochemical conditions at methane seeps are characterised by opposing gradients of porewater sulphate $\left(\mathrm{SO}_{4}{ }^{2-}\right)$ and methane. A biogeochemical zone, the sulphate-methane transition zone (SMTZ), is established close or up to several metres below the seafloor, where microbial co-metabolism counterbalances the upward flux of methane and the downward flux of sulphate (Reeburgh, 1976; Whiticar and Faber, 1986; Valentine, 2002; Tryon, et al. 1999). A changing methane flux can cause vertical migration of the SMTZ through the sediment (Borowski et al., 1996). A key geochemical process at the SMTZ (Eq. 1) is the microbially mediated anaerobic oxidation of methane (AOM) involving syntrophic consortia of methane-oxidizing archaea and sulphate-reducing bacteria (Knittel and Boetius, 2009 and references therein):

Reducing conditions at the SMTZ can result in reductive dissolution of magnetic Fe-oxides (Canfield and Berner, 1987; Peckmann et al., 2001; Riedinger et al., 2005; Novosel et al., 2005; Dewangen et al., 2013) and alteration of the initial sediment composition and magnetic properties due to replacement of magnetic Fe-oxides by paramagnetic authigenic Fe-sulfides (Ferrell and Aharon, 1994; Bohrmann et al., 1998; Rodriguez et al., 2000; Greinert et al., 2001; März et al., 2008; Lin et al., 2016; 2017). Barium $\left(\mathrm{Ba}^{2+}\right)$ that is present dissolved in seep fluids (Hanor, 2000; Torres et al., 2003a) can react with porewater sulphate and can precipitate as authigenic barite $\left(\mathrm{BaSO}_{4}\right)$ at the upper boundary of the SMTZ (Torres et al., 1996, Dickens, 2001; Paytan et al., 2002; Riedinger at el., 2006; Kasten et al., 2012; Sauer et al., 2017). As porewater sulphate is depleted underneath the SMTZ, buried barite dissolves and barium diffuses upward to the SMTZ where it re-precipitates as authigenic barite (Torres et al., 1996; Dickens, 2001). Barite fronts are commonly found immediately above the present-day depth of 
porewater sulphate depletion (Dickens, 2001; Riedinger et al., 2006) and serve as a geochemical tracer for the SMTZ.

The SMTZ is also the sedimentary interval where MDAC precipitates. The AOM (Eq. 1) elevates the porewater alkalinity (Ritger et al., 1986; Paull et al., 1992), and thus promotes the precipitation of $\mathrm{Ca}(\mathrm{Mg} / \mathrm{Sr}) \mathrm{CO}_{3}$ (Eq. 2):

$$
2 \mathrm{HCO}_{3}{ }^{-}+\mathrm{Ca}^{2+}\left(\mathrm{Mg}^{2+} / \mathrm{Sr}^{2+}\right) \rightarrow \mathrm{Ca}(\mathrm{Mg} / \mathrm{Sr}) \mathrm{CO}_{3}+\mathrm{CO}_{2}+\mathrm{H}_{2} \mathrm{O}
$$

Carbonates with $\delta^{13} \mathrm{C}$ values more negative than -30\% VPDB are consistent with carbon sourced from AOM (Whiticar, 1999; Aloisi et al., 2000; Bohrmann et al., 2001; Greinert et al., 2001; Naehr et al., 2007). MDAC is often composed of aragonite, high-Mg calcite (5-20mol\% $\mathrm{MgCO}_{3}$, Burton 1993), or dolomite (Bohrmann et al., 1998; 2001; Aloisi et al., 2000; Greinert et al., 2001, Naehr et al., 2007) and occur as early diagenetic micrite-cemented nodules, cavity fills, coatings, or crusts on the seafloor (Bohrmann et al., 1998; 2002; Mazzini et al., 2004; Bayon et al., 2009; Crémière et al., 2016a; Sauer et al., 2017). Aragonite and high-Mg calcite precipitate near the seafloor and indicate that the SMTZ was located in the shallow subsurface (cm or dm scale) during episodes of high $\mathrm{CH}_{4}$-flux (Aloisi et al., 2000; Greinert et al., 2001; Naehr et al., 2007). It was suggested that large MDAC crusts require time spans of hundreds to thousands of years to form and often yield different ages compared to their host sediment (Teichert et al., 2003; Bayon et al., 2009; Luff et al., 2004; 2005).

Together with fossil remains of seep fauna, MDAC provides direct geological evidence of AOM and methane seepage in the sedimentary record. Panieri et al. (2017a) showed that foraminifera serve as preferred nucleation templates for authigenic Mg-calcite precipitation at methane seeps. Negative $\delta^{13} \mathrm{C}$ excursions from benthic foraminifera in sedimentary records have been used to identify periodic release of methane stored in gas hydrates at various times in earth history (Dickens, 1997; Kennet et al., 2000; Thomas et al., 2002; Jenkyns et al., 2003; Tripati and Elderfield, 2005; Zachos et al., 2007). Several studies have shown that MDAC precipitates form coatings around foraminiferal tests and may 
overprint the primary shell mineralogy and stable isotope composition, which complicates the use of foraminiferal $\delta^{13} \mathrm{C}$ records as past seepage archives (Rathburn et al. 2000; Torres et al., 2003b; 2010; Martin et al., 2010; Panieri et al., 2009; 2014; 2017a; Consolaro et al., 2015; Schneider et al., 2017).

\section{Study area}

Vestnesa Ridge is located at $79^{\circ} \mathrm{N}$ on the western continental margin of the Svalbard Archipelago (Fig. $1 \mathrm{a}$; b). The ridge, in 1200-1300 m water depth, is approximately $100 \mathrm{~km}$ long and composed of $>2 \mathrm{~km}$ thick Pliocene and Pleistocene sediments overlying $<20$ million years (Ma) old oceanic crust (Eiken and Hinz, 1993; Engen et al., 2008). The youngest sediments of Late Pleistocene and Holocene age are silty turbidites, muddy-silty contourites, and hemipelagites (Vogt et al., 1994; 1999; Howe et al., 2008).

Seeps at Vestnesa Ridge produce up to $900 \mathrm{~m}$ high gas flares that probably emit a mixture of microbial and thermogenic gas (Smith et al., 2014; Panieri et al., 2017b). A Bottom Simulating Reflector (BSR) located $\sim 160-180 \mathrm{~m}$ bsf (meters below seafloor) as well as an underlying zone of high amplitudes and anomalously low seismic velocities indicate the presence of free gas at the base of the GHSZ (Petersen et al., 2010; Goswami et al., 2015; Plaza-Faverola et al., 2015). Vertical fluid flow conduits (chimneys) cross the BSR, intersect the overlying sediments, connect to the seafloor at pockmarks, and thus allow vertical fluid migration (Petersen et al., 2010; Bünz et al., 2012). Circular seafloor depressions, known as pockmarks, have a diameter of up to $700 \mathrm{~m}$, align along the crest of Vestnesa Ridge, and have a complex topography with ridge-like structures and sub-depressions (pits) of ca. $50 \mathrm{~m}$ in diameter (Vogt et al., 1994; Bünz et al., 2012; Panieri et al., 2017b; Fig. 1c). Seepage within the pockmarks Lunde and Lomvi (Fig. 1c) is heterogeneous. The presence of bacterial mats and chemosynthetic tubeworms suggest slow and pervasive (diffuse) fluid flow, while flares originating from pits (ca. 50m in diameter) within the pockmarks and with sparse carbonate blocks at the seafloor may be evidence of strong (focused) fluid flow (Panieri et al., 2017b). The pockmarks are actively releasing gases into the water column in the south-eastern segment of Vestnesa Ridge but are inactive in the north-western segment (Bünz et al., 2012; Smith et al., 2014; Plaza-Faverola et al., 2015). Several seepage episodes since the 
onset of Northern Hemispheric glaciations, ca. 2.7 Ma ago, and within the last $17 \mathrm{cal}$ ka have been inferred from seismic interpretation of buried pockmarks and mounds within chimney structures and foraminiferal stable carbon isotope records (Panieri et al., 2014; Consolaro et al., 2015; Plaza-Faverola et al., 2015; Schneider et al., 2017; Sztybor and Rasmussen 2017a). It has been suggested that an active petroleum system was established offshore north-western Svalbard approximately 6 Ma ago when hydrocarbon generation from deeply buried Miocene source rocks commenced (Knies et al. 2018). Vestnesa Ridge is located between the western Svalbard continental margin and the ultra-slow spreading Arctic ridge systems in the Fram Strait (Fig. 1a) (Talwani and Eldholm, 1977; Engen et al., 2008; Johnson et al., 2015). It is bounded by the Spitsbergen Transform Fault and the ultraslow spreading Molloy Ridge to the north, and the Molloy Transform Fault and the Knipovich Ridge to the south (Crane et al., 2001; Vanneste et al., 2005; Winkelmann et al., 2008; Plaza-Faverola et al., 2015; Johnson et al., 2015; Fig. 1a; b). Faulting and fracturing in response to tectonic stress variations over the past 2.7 $\mathrm{Ma}$ is believed to exert an important control on seepage activity along the ridge (PlazaFaverola et al., 2015).

Two water masses dominate the present-day oceanographic setting of the Fram Strait: the West Spitsbergen Current (WSC) and the East Greenland Current (EGC). The WSC, which is the northernmost branch of the warm and saline Norwegian Atlantic Current, moves northwards along the western Svalbard continental margin (Aagaard et al., 1987). It sustains ice-free conditions in the eastern Fram Strait throughout most of the year and transports Atlantic water into the Arctic Ocean (Schauer et al., 2004; Cokelet et al., 2008; Beszczynska-Möller et al., 2012; Rebesco et al., 2013). The EGC runs southwards in the western Fram Strait and transports cold and less saline Polar Surface Water into the Atlantic (Aagaard et al., 1987; Woodgate et al., 1995; Beszczynska-Möller et al., 2012). 

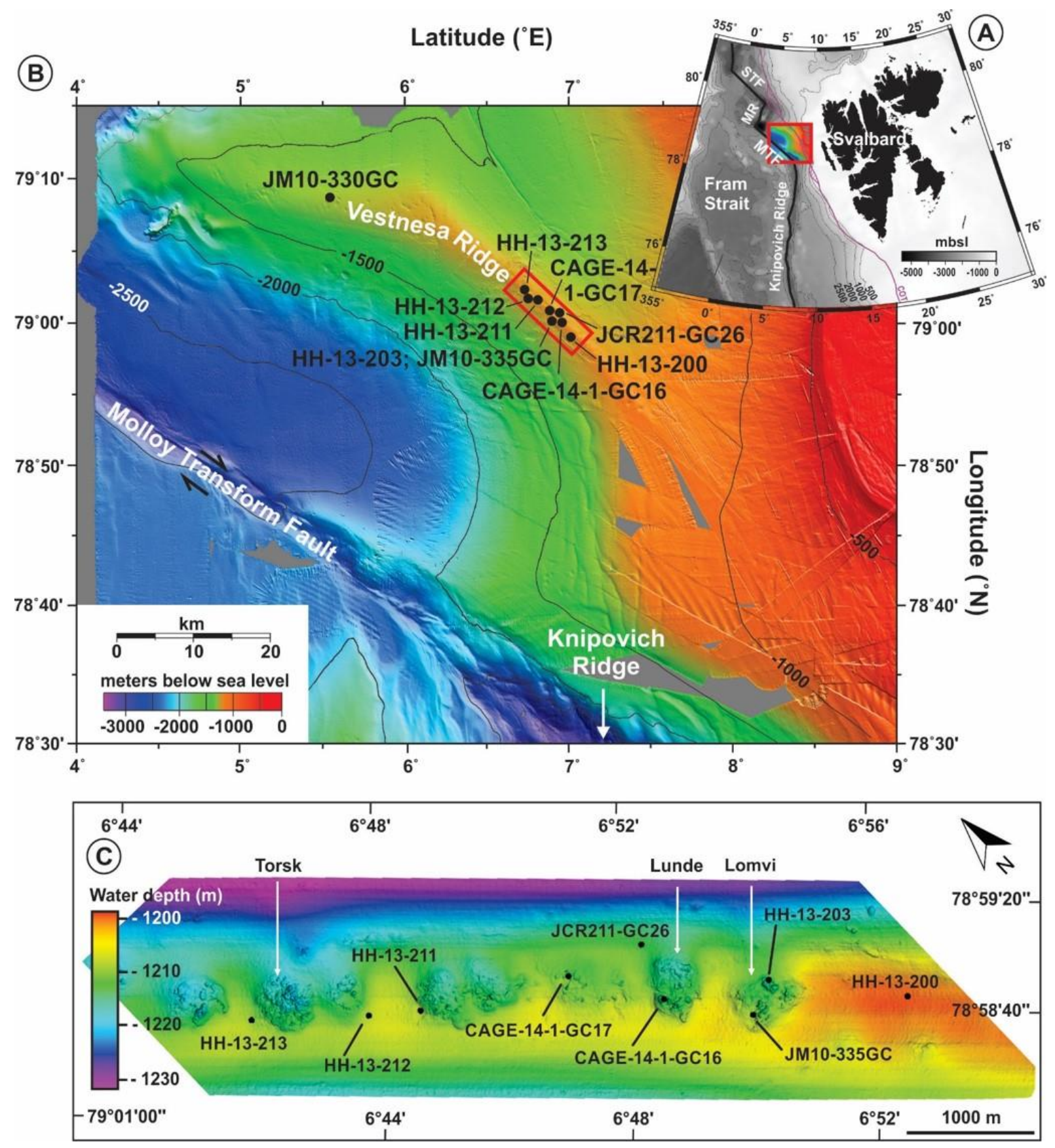

Fig. 1. (A) IBCAO map of the western Svalbard margin and eastern Fram Strait (Jakobsson et al., 2012).

The red square indicates the location of $\mathrm{B}$. The continent-ocean transition (COT) is delineated in purple.

Swath bathymetry map of Vestnesa Ridge with the location of the studied cores. The red square indicates the location of (C). Modified from Hustoft et al. (2009). (C) Seafloor reflection map from high resolution 3D seismic data ( $6 \times 6 \mathrm{~m}$ bin size) showing the pockmark field on the south-eastern Vestnesa 
Ridge segment and projection of the studied cores. Pockmark names Lunde, Lomvi, and Torsk in accordance with Panieri et al. (2017b).

\section{Methods}

\subsection{Core collection and description}

211

In this study, we examine ten sediment gravity cores collected from Vestnesa Ridge between 2008 and 2014 (Table 1). Eight cores were retrieved from the south-eastern segment of Vestnesa Ridge that has active pockmarks (Fig. 1b). Core $\mathrm{HH}-13-200$ was recovered from the southernmost location $3.5 \mathrm{~km}$ away from the nearest active pockmark (Lomvi). In contrast, sediment core JM10-330GC was taken from an inactive pockmark at the north-western ridge segment. Reference core HH-13-212 was collected from a site where modern and paleo-seepage evidence was absent. The coring transect covers $35.8 \mathrm{~km}$ with distances between the cores varying from 0.1 to $27.7 \mathrm{~km}$ (Table 1 ). Selected results from these cores have been published elsewhere (Table 1).

After recovery, the cores were cut into $100 \mathrm{~cm}$ sections, split longitudinally, and kept cool at $5^{\circ} \mathrm{C}$. All following sediment descriptions and analyses have been performed at UiT The Arctic University of Norway in Troms $\varnothing$. Magnetic susceptibility (MS) and bulk density (BD) were measured in $1 \mathrm{~cm}$ intervals using a GeoTek Multi-Sensor Core Logger (MSCL). The cores were described visually, X-ray-scanned (Geotek MSCL-XR 3.0), and photographed (Jai L-107CC 3 CCD RGB Line Scan Camera).

For reference core $\mathrm{HH}-13-212$, ice-rafted debris (IRD, size $>2 \mathrm{~mm}$ ) was counted using X-ray scans. Geochemical data from selected cores (HH-13-200; -203; -211; -213) were acquired with an Avaatech XRF Core Scanner at $1 \mathrm{~cm}$ steps using the following settings: down-core slit size $10 \mathrm{~mm}$; cross-core slit size $12 \mathrm{~mm} ; 10 \mathrm{kV} ; 1000 \mu \mathrm{A}$; no filter; and 10 seconds measuring time per step; same settings but 50 kV and 20 seconds measuring time per step for barium. The raw data were subsequently processed with the software WinAxil. For the purpose of this study, we report the strontium (Sr), calcium (Ca), barium ( $\mathrm{Ba}$ ), and sulphur $(\mathrm{S})$ counts normalised to either titanium (Ti) or to the sum of the eight most 
common elements in our records (Sum8), which are silicon, strontium, potassium, calcium, zirconium,

232 rubidium, titanium, and iron.

234 Table 1. Coring coordinates, year of recovery, sediment recovery, depth, distance between cores,

235 and seafloor setting of the sediment gravity cores used in this study. Cores are listed from SE to NW.

\begin{tabular}{|c|c|c|c|c|c|c|c|}
\hline Core ID & Coordinates & Year & $\begin{array}{l}\text { Recovery } \\
(\mathrm{cm})\end{array}$ & $\begin{array}{l}\text { Depth } \\
\text { (m bsf) }\end{array}$ & $\begin{array}{l}\text { Distance } \\
\text { to next } \\
\text { core }(\mathbf{k m})\end{array}$ & $\begin{array}{l}\text { Seafloor } \\
\text { setting }\end{array}$ & Reference and cruise \\
\hline $\mathrm{HH}-13-200$ & $\begin{array}{l}78.981^{\circ} \mathrm{N} \\
7.061^{\circ} \mathrm{E}\end{array}$ & 2013 & 270 & 1205 & 3.70 & $\begin{array}{l}\text { Undisturbed } \\
\text { seafloor }\end{array}$ & $\begin{array}{l}\text { This study; } \\
\text { Cruise CAGE-HH-2013 }\end{array}$ \\
\hline $\mathrm{HH}-13-203$ & $\begin{array}{c}79.002^{\circ} \mathrm{N} \\
6.928^{\circ} \mathrm{E}\end{array}$ & 2013 & 300 & 1210 & 0.1 & $\begin{array}{l}\text { Pockmark } \\
\text { with flare } \\
\text { (Lomvi) }\end{array}$ & $\begin{array}{l}\text { Ambrose et al., 2015; } \\
\text { Schneider et al., } \\
\text { 2017; } \\
\text { Cruise CAGE-HH-2013 }\end{array}$ \\
\hline JM10-335GC & $\begin{array}{c}79.002^{\circ} \mathrm{N} \\
6.922^{\circ} \mathrm{E}\end{array}$ & 2010 & 485 & 1197 & 0.7 & $\begin{array}{l}\text { Pockmark } \\
\text { with flare } \\
\text { (Lomvi) }\end{array}$ & $\begin{array}{l}\text { Sztybor and } \\
\text { Rasmussen 2017a; } \\
\text { Cruise JM10 }\end{array}$ \\
\hline $\begin{array}{l}\text { CAGE-14-1- } \\
\text { GC16 }\end{array}$ & $\begin{array}{c}79.008^{\circ} \mathrm{N} \\
6.900^{\circ} \mathrm{E}\end{array}$ & 2014 & 475 & 1217 & 0.46 & $\begin{array}{l}\text { Pockmark } \\
\text { with flare } \\
\text { (Lunde) }\end{array}$ & $\begin{array}{l}\text { This study; } \\
\text { Cruise CAGE 14-1 }\end{array}$ \\
\hline JCR211-GC26 & $\begin{array}{c}79.011^{\circ} \mathrm{N} \\
6.907^{\circ} \mathrm{E}\end{array}$ & 2008 & 386 & 1210 & 0.60 & $\begin{array}{l}\text { Pockmark } \\
\text { with flare }\end{array}$ & $\begin{array}{l}\text { Panieri et al., 2014; } \\
\text { Cruise JR211 }\end{array}$ \\
\hline $\begin{array}{l}\text { CAGE-14-1- } \\
\text { GC17 }\end{array}$ & $\begin{array}{c}79.013^{\circ} \mathrm{N} \\
6.880^{\circ} \mathrm{E}\end{array}$ & 2014 & 440 & 1207 & 1.18 & Pockmark & $\begin{array}{l}\text { This study; } \\
\text { Cruise CAGE 14-1 }\end{array}$ \\
\hline $\mathrm{HH}-13-211$ & $\begin{array}{c}79.018^{\circ} \mathrm{N} \\
6.831^{\circ} \mathrm{E}\end{array}$ & 2013 & 498 & 1202 & 0.40 & Pockmark & $\begin{array}{l}\text { Ambrose et al., 2015; } \\
\text { Cruise CAGE-HH-2013 }\end{array}$ \\
\hline $\mathrm{HH}-13-212$ & $\begin{array}{c}79.020^{\circ} \mathrm{N} \\
6.816^{\circ} \mathrm{E}\end{array}$ & 2013 & 519 & 1202 & 0.91 & $\begin{array}{l}\text { Undisturbed } \\
\text { seafloor }\end{array}$ & $\begin{array}{l}\text { Reference core } \\
\text { This study; } \\
\text { Cruise CAGE-HH-2013 }\end{array}$ \\
\hline $\mathrm{HH}-13-213$ & $\begin{array}{c}79.025^{\circ} \mathrm{N} \\
6.782^{\circ} \mathrm{E}\end{array}$ & 2013 & 520 & 1203 & 27.76 & $\begin{array}{l}\text { Pockmark } \\
\text { with flare } \\
\text { (Torsk) }\end{array}$ & $\begin{array}{l}\text { This study; } \\
\text { Cruise CAGE-HH-2013 }\end{array}$ \\
\hline JM10-330GC & $\begin{array}{l}79.130^{\circ} \mathrm{N} \\
5.600^{\circ} \mathrm{E}\end{array}$ & 2010 & 420 & 1300 & & Pockmark & $\begin{array}{l}\text { Consolaro et al., } \\
\text { 2015; Cruise JM10 }\end{array}$ \\
\hline
\end{tabular}

240 Stratigraphic correlation of the sediment cores is obtained through radiocarbon-dated MS records and

241 associated tie points known from established stratigraphic marker horizons at the western Svalbard 
continental margin (Table 2, Jessen et al., 2010; Sztybor and Rasmussen, 2017a). All calibrated ages presented in the following text will be in calendar years before present (cal BP) A.D. 1950 with a standard deviation of $2 \sigma$.

Defined stratigraphic marker horizons include clast-rich laminated sediments (within the LGM; 24-23.5 ka), fine-grained laminated sediments (Bølling interstadial; 14.7-14.3 ka), and a structureless layer rich in Coscinodiscus spp. diatoms (Early Holocene; 10.1-9.8 ka) that have been traced along the western Svalbard continental margin between 76 and $79^{\circ} \mathrm{N}$ by Jessen et al. (2010; Table 2). Both the structureless diatom-rich layer and the laminated sediments require microscopic examinations of the sediment or X-ray scanning for detection. The clast-rich laminated sediment can be identified as a dark sediment layer that is characterised by a sharp drop in MS, gradually increasing BD throughout the interval, and abundant IRD (Jessen et al., 2010).

Sztybor and Rasmussen (2017a) proposed the correlation of the established stratigraphic marker horizons to the Vestnesa Ridge and provided additional radiocarbon ages. Some of the dates were performed on foraminiferal samples having low $\delta^{13} \mathrm{C}$ that were clearly affected by diagenetic alteration. Radiocarbon dates obtained from such altered samples yield an older age due to exposure to methane-derived dissolved inorganic carbon and diagenetic alteration (Uchida et al., 2008). For this paper, we only use a selection of the ages obtained by Ambrose et al. (2015) and Sztybor and Rasmussen (2017a) where $\delta^{13} \mathrm{C}$ signature is characteristic of normal marine conditions.

Table 2. Stratigraphic tie points (TP) and marker horizons from the western Svalbard continental margin used for core correlation.

\begin{tabular}{lcccc}
\hline Interval & Min. Age & Max. Age & TP & Reference \\
& cal years BP & cal years BP & \\
\hline Diatom-rich layer & $9,840 \pm 200$ & $10,100 \pm 150$ & $2 ; 3$ & $\begin{array}{l}\text { Jansen et al., 1983; Stabell, } \\
\text { 1986; Jessen et al., 2010; } \\
\end{array}$ \\
& & Müller and Stein, 2014
\end{tabular}




\begin{tabular}{|c|c|c|c|c|}
\hline $\begin{array}{l}\text { Local MS max above } \\
\text { laminated sediment } \\
\text { interval }\end{array}$ & $14,070 \pm 210$ & & 4 & Jessen et al., 2010 \\
\hline $\begin{array}{l}\text { Laminated sediment } \\
\text { interval }\end{array}$ & $14,300 \pm 260$ & $14,780 \pm 220$ & $5 ; 6$ & $\begin{array}{l}\text { Elverhøi et al., 1995; Birgel } \\
\text { and Hass, 2004; Jessen et al., } \\
\text { 2010; Lucchi et al., } 2015\end{array}$ \\
\hline Event 1 & $23,550 \pm 185$ & $24,080 \pm 150$ & $7 ; 8$ & $\begin{array}{l}\text { Knies and Stein, 1998; Vogt et } \\
\text { al., 2001; Jessen et al., } 2010\end{array}$ \\
\hline $\begin{array}{l}\text { Nearest local MS min } \\
\text { below Event } 1\end{array}$ & $27,500 \pm 270$ & & 9 & Jessen et al., 2010 \\
\hline
\end{tabular}

We have further improved the stratigraphic control with one additional ${ }^{14} \mathrm{C}$ AMS radiocarbon age. The additional radiocarbon dating was carried out at the Beta Analytic Radiocarbon Dating facilities in Miami, US. A conventional radiocarbon age of 28,090 +/- 150 years was obtained from a basal sample of core $\mathrm{HH}-13-213$ (455 cm, laboratory code Beta-456619). The age was converted into calendar years using the calibration program Calib 7.1 (Stuiver et al., 2014) with a marine reservoir age of -400 years that was incorporated within the Marine13 calibration curve (Reimer et al., 2013). In addition, a regional reservoir age correction $\Delta \mathrm{R}$ of $7 \pm 11$ was applied (Mangerud et al., 2006). The age model is based on the calibrated ages obtained from the peaks of the probability curves within the $2 \sigma$ range. The calibrated result was an age of 29,490 +/- 287 years BP. Based on the stratigraphic tie points (Table 2) and the additional radiocarbon age, we calculate linear sedimentation rates for the stratigraphic marker horizons and the intermediate sediment intervals (supplementary material S1).

\subsection{Stable isotope analyses of foraminifera}

Samples for stable isotope analysis of foraminiferal calcite tests were typically collected at $10 \mathrm{~cm}$ intervals and at $5 \mathrm{~cm}$ intervals from the reference core $\mathrm{HH}-13-212$ (Table S2). Samples from cores $\mathrm{HH}$ 13-203 (depth interval from 220 to $270 \mathrm{~cm}$ ) and $\mathrm{HH}-13-211$ (depth interval from 390 to $470 \mathrm{~cm}$ ) were obtained at higher spatial resolution (Table S2). The samples were wet-weighed, freeze-dried, dryweighted, and wet-sieved (mesh sizes $63 \mu \mathrm{m}, 100 \mu \mathrm{m}, 1 \mathrm{~mm}$ ). The sieve residues were dried at $40^{\circ} \mathrm{C}$ 
and subsequently investigated using optical microscopes. Benthic (Cassidulina neoteretis [Seidenkrantz, 1995]; Melonis barleeanus [Williamson, 1858]) and planktic foraminifera (Neogloboquadrina pachyderma sinistral (sin) [Ehrenberg, 1861]) were picked for isotope measurements from the dry residue of the $>100 \mu \mathrm{m}$ size fraction. Those species were selected since they are abundant throughout the cores, and common in the Arctic Ocean (Wollenburg and Mackensen 1998; Wollenburg et al., 2001; Zamelczyk et al., 2012). The same foraminiferal species have been used in similar studies from Vestnesa Ridge (Table 1).

Stable oxygen $\left(\delta^{18} \mathrm{O}\right)$ and carbon $\left({ }^{13} \mathrm{C}\right)$ isotope analyses of foraminiferal tests were performed using a ThermoFinnigan MAT252 mass spectrometer coupled to a CarboKiel-II carbonate preparation device at the Serveis Cientifico-Técnics of the University in Barcelona in Spain. Each sample of Cassidulina neoteretis (236 samples), M. barleeanus (18 samples), N. pachyderma sin (172 samples) consists of 15 to 30 tests. Analytical precision was estimated to be better than $\pm 0.08 \%$ or oxygen and $\pm 0.03 \%$ o for carbon by measuring the certified standard NBS-19. We report all isotope results in standard delta notation relative to Vienna Pee Dee Belemnite (VPDB). For already published stable isotope records that are included in this study, details for sample preparation and stable isotope measurements can be found in the references given in Table 1.

\subsection{MDAC analyses - stable isotopes and mineralogy}

Stable oxygen and carbon isotope analyses of 37 authigenic carbonate nodules from different cores were performed using a ThermoScientific MAT253 mass spectrometer coupled to a Finnigan Gasbench II at the Stable Isotope Laboratory at UiT The Arctic University of Norway in Troms $\varnothing$. Analytical precision was estimated to be better than $\pm 0.07 \%$ VPDB.

Where enough material was present, we performed XRD analyses of unoriented carbonate samples using a Bruker D8 Advance X-ray diffractometer ( $\mathrm{Cu} \mathrm{K}$ radiation in $3-75^{\circ} 2 \theta$ range) at the Geological Survey of Norway in Trondheim. The quantitative mineralogical composition of the carbonate phases was interpreted and modelled by using the Rietveld algorithm-based code Topas-4 by Bruker. 
Following a displacement correction of the spectrum made on the main quartz peak, the displacement

311 of calcite $d_{104}$ was used to estimate the amount of $\mathrm{MgCO}_{3}$ mol \% (Goldsmith and Graf, 1958).

\subsection{Lithology, chronology and core correlation} in brief article.

\subsubsection{Reference core $\mathrm{HH}-13-212$ and regional correlations}

The $519 \mathrm{~cm}$ long reference core HH-13-212 was collected outside pockmarks on the crest of Vestnesa Ridge where methane seepage is absent. The core is composed of silty clay with intervals rich in IRD and includes all three main stratigraphic marker horizons for the western Svalbard continental margin spanning from the LGM to the Early Holocene (Tab. 3; Fig. 2). The diatom-rich interval occurs in the top $5 \mathrm{~cm}$ of the core (max. age $10.1 \mathrm{ka} \mathrm{BP}$; Early Holocene), laminated sediments occur between $65 \mathrm{~cm}$ (14.3 ka BP) and $155 \mathrm{~cm}$ (14.7 ka BP; Bølling), and dark laminated coarser sediment occurs at 309-353 cm (24-23.5 ka BP; within the LGM; Tab. 3; Fig. 2). This interval is known as "Event 1" (Knies and Stein, 1998) and is dated to approximately $23-19.4{ }^{14} \mathrm{C}$ ka BP (Elverhoi, 1995; Andersen et al., 1996; Vogt et al., 2001) or 24 ka BP ( ${ }^{14} \mathrm{C}$ age: $20,040 \pm 325$; lab code KIA365, Knies and Stein, 1998).

The MS values largely follow the western Svalbard MS stack curve (Jessen et al., 2010, Fig. 2). For the description of the lithology and foraminifera content of core $\mathrm{HH}-13-212$, the main stratigraphic marker horizons, and major paleoceanographic and environmental changes the reader is referred to the data 

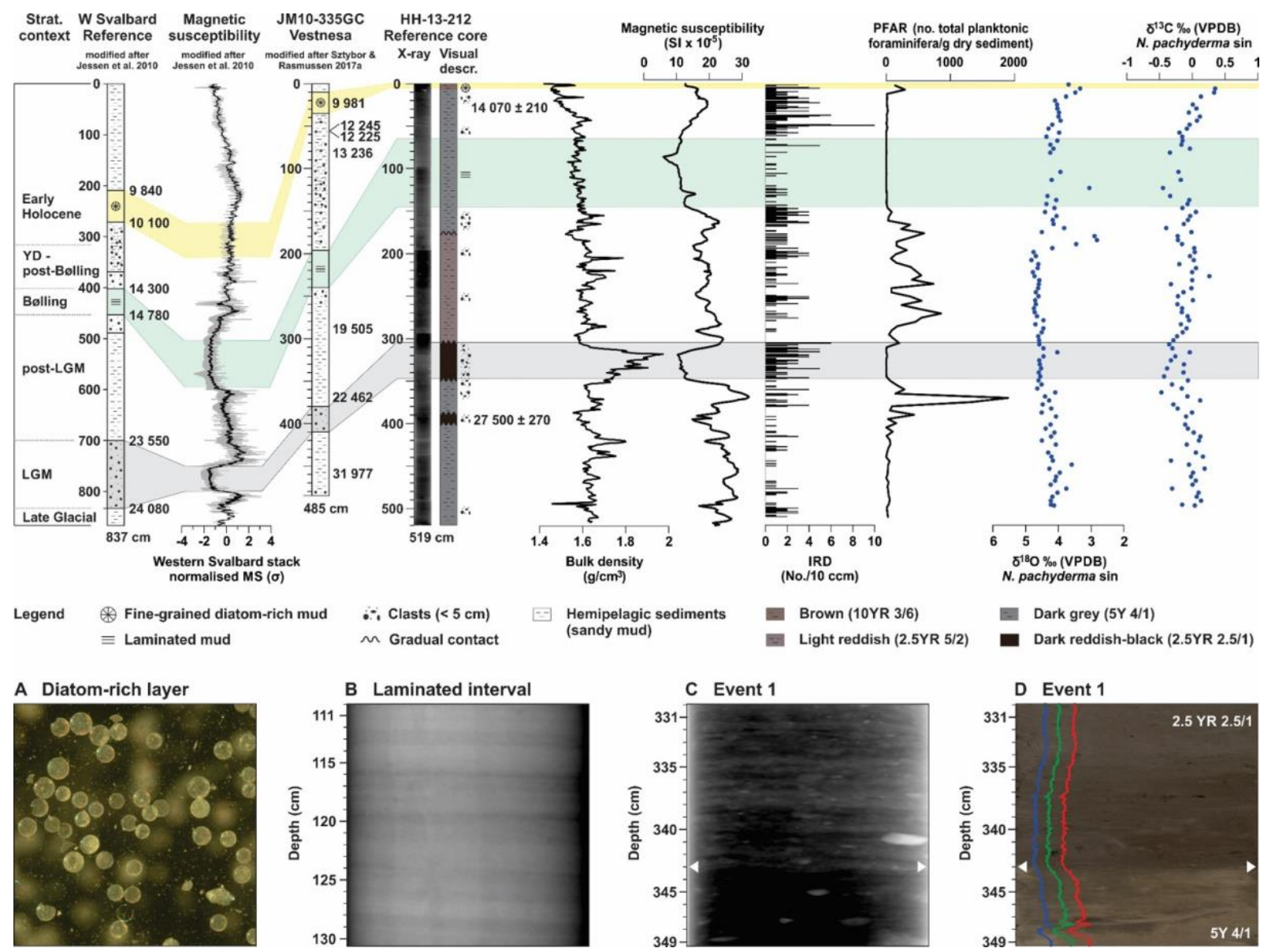

Fig. 2. Lithology and magnetic susceptibility (MS) of the western Svalbard reference record obtained by Jessen et al. (2010). Lithology of core JM10-335GC modified after Sztybor and Rasmussen (2017a). X-ray image, lithology, BD, MS, IRD content, PFAR (planktic foraminiferal accumulation rate), stable oxygen and carbon isotope records from N. pachyderma sin from Vestnesa Ridge reference core HH13-212. LGM - Last Glacial Maximum. HE 1 - Heinrich Event 1. YD - Younger Dryas. The negative MS peaks at 100 and $500 \mathrm{~cm}$ are artefacts due to change in core section. (A) Diatom-rich interval. Photograph of the $>63 \mu \mathrm{m}$ fraction from microscope, magnification is $16 \mathrm{x}$. $\mathrm{HH}-13-212,5 \mathrm{~cm}$ bsf. (B) Laminated interval. X-ray scan of fine-grained laminated sediments. HH-13-212, 110-131 cm bsf. (C)

Event 1 sediments. X-ray scan of fine-grained laminated sediment providing a matrix for abundant gravel sized clasts. HH-13-212, 330-350 cm bsf. (D) Event 1 sediments. Colour scan, RGB colour values, and lower contact of the Event 1 interval. $\mathrm{HH}-13-212,330-350 \mathrm{~cm}$ bsf. An arrow in panels C and D marks the base of the Event 1 sediments. 
351

352

353

354

355

The eight sediment cores recovered from active or inactive pockmarks, and the southernmost core HH-13-200, consist of dark grey silty clay of late Pleistocene and Early Holocene age with layers rich in IRD and shell fragments (Fig. 3).

Magnetic susceptibility signals are typically low (Table 4). This is common in methane seeps where iron-oxides such as ferromagnetic magnetite $\left(\mathrm{Fe}_{3} \mathrm{O}_{4}\right)$ are exposed to hydrogen-sulphide produced by AOM, experience reduction to paramagnetic pyrite $\left(\mathrm{FeS}_{2}\right)$, and cause significant reduction or loss of the MS signal (Canfield and Berner, 1987; Riedinger et al., 2005; März et al., 2008; Dewangan et al., 2013). Nevertheless, all three typical stratigraphic marker horizons can be recognised in most of the sediment cores and allow core correlation (Table 3). The $25-50 \mathrm{~cm}$ thick Event 1 sediments were identified based on X-ray images and a reddish-black layer (Munsell colour: 2.5YR 2.5/1) in cores CAGE14-1-GC16; CAGE-14-1-GC17; HH-13-211, and HH-13-213. A radiocarbon date of 24,743 years BP at $460.5 \mathrm{~cm}$ obtained from planktic foraminifera confirms the upper boundary of Event 1 (Ambrose et al., 2015). The total thickness of the laminated interval varies between $30 \mathrm{~cm}$ and $90 \mathrm{~cm}$. In most cores, the interval rich in Coscinodiscus spp. diatoms occurs at or near the core top, indicating Early Holoceneaged sediments near the seafloor. The calculated linear sedimentation rates reveal rapid sedimentation during the LGM $\left(75-90 \mathrm{~cm} \mathrm{ka}^{-1}\right)$ and the Early Holocene $\left(67-188 \mathrm{~cm} \mathrm{ka}^{-1}\right.$; supplementary material S1).

Interestingly, sediment cores from the western Svalbard continental shelf and slope, including the south-eastern Vestnesa Ridge segment, share the absence of Early Holocene sediments (Elverhøi et al., 1995; Howe et al., 2008; Sztybor and Rasmussen 2017a; 2017b), presumably due to the erosive force of the WSC resulting in non-deposition or sediment removal. Mooring studies across the Fram Strait reveal the present-day WSC has two branches with a narrow and strong core shallower than $1000 \mathrm{~m}$ and maximum northwards velocities of $20 \mathrm{~cm} \mathrm{~s}^{-1}$, and an offshore branch below $1400 \mathrm{~m}$ with northwards velocities of 5-10 $\mathrm{cm} \mathrm{s}^{-1}$ (Beszczynska-Möller et al., 2012; Rebesco et al. 2013). The strong 
375 WSC core may have winnowed unconsolidated fine-grained sediments from the easternmost part of

376 Vestnesa Ridge, explaining the narrow and sharp bathymetric expression of the ridge along its eastern

377 segment (Fig. 1). In contrast, the north-western ridge segment, located in $1300 \mathrm{~m}$ water depth, has a

378 more widespread and gently rounded geometry. It may have experienced less strong current velocities

379 and therefore retained Holocene sediments.

380

381 


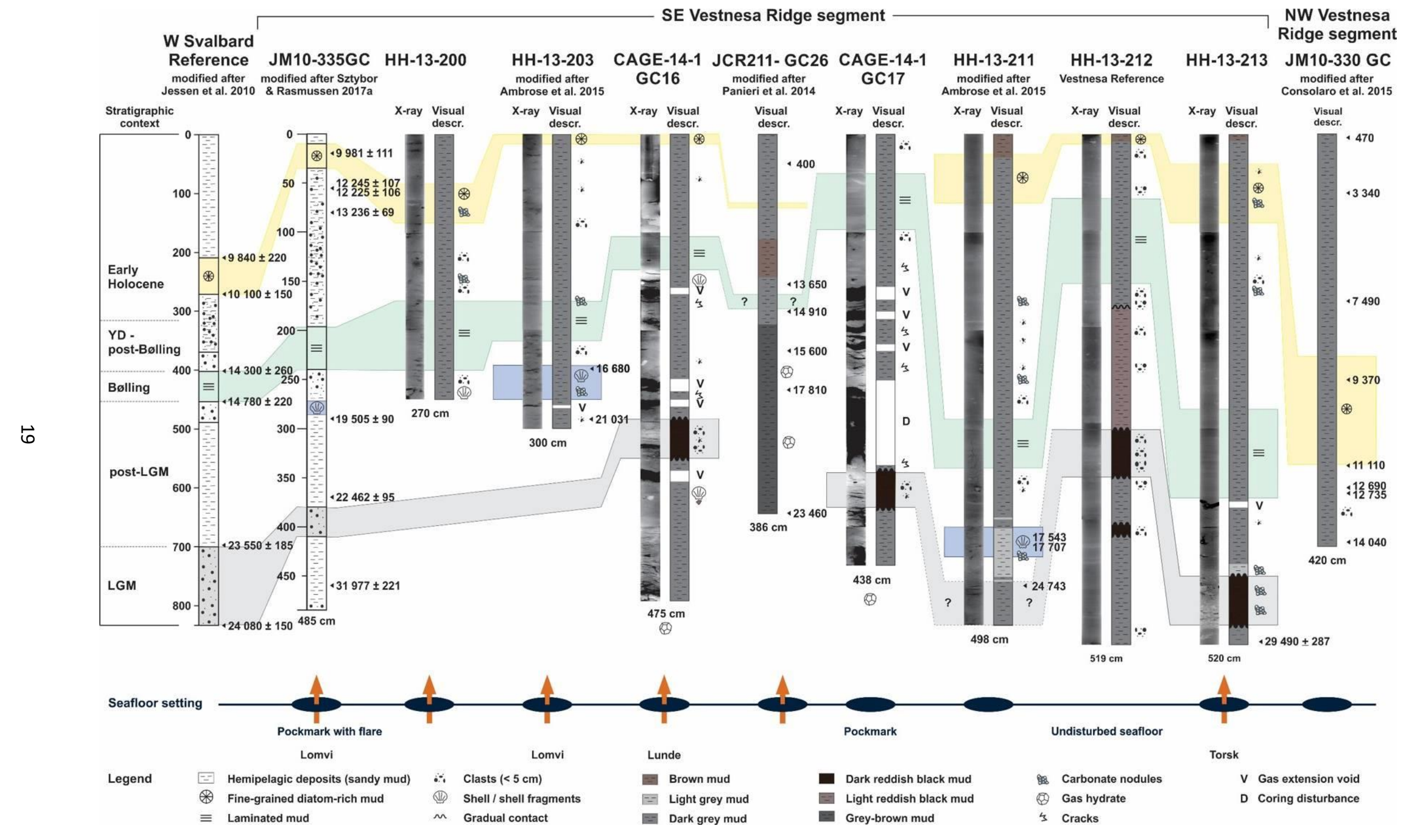


Fig. 3. Core description and correlation with published records from Vestnesa Ridge and the western Svalbard margin. Note the different depth scale on the W Svalbard reference record. The depth of the laminated sediments in core JCR211-GC26 was estimated assuming linear sedimentation between the ages obtained by Panieri et al. (2014). Pockmark names according to Panieri et al. (2017b). LGM - Last Glacial Maximum. HE 1 - Heinrich Event 1. YD - Younger Dryas.

Table 3. Depth intervals of the main sedimentary units and fossil content, given in $\mathrm{cm}$ below seafloor (bsf). *The depth of the laminated sediments in core JCR211-GC26 was estimated assuming linear sedimentation between the ages obtained by Panieri et al. (2014). bsf - below sea floor.

\begin{tabular}{lllll}
\hline Core ID & $\begin{array}{l}\text { Diatom-rich } \\
\text { sediments }\end{array}$ & $\begin{array}{l}\text { Laminated } \\
\text { sediments } \\
\text { cm bsf }\end{array}$ & $\begin{array}{l}\text { Shell bed } \\
\text { interval } \\
\text { cm bsf }\end{array}$ & $\begin{array}{l}\text { Event 1 } \\
\text { sediments } \\
\text { cm bsf }\end{array}$ \\
\hline HH-13-200 & $50-90$ & $170-240$ & - & - \\
HH-13-203 & $0-10$ & $172-210$ & $236-268$ & - \\
JM10-335GC & $10-35$ & $200-240$ & 278 & $380-410$ \\
CAGE-14-1-GC16 & $0-10$ & $105-137$ & - & $290-330$ \\
JCR211-GC26 & $117-120$ & $167-178 *$ & - & - \\
CAGE-14-1-GC17 & - & $40-98$ & - & $347-372$ \\
HH-13-211 & $20-70$ & $287-340$ & $400-430$ & $?(>465)$ \\
HH-13-212 & $0-5$ & $65-155$ & - & $309-343$ \\
HH-13-213 & $30-90$ & $280-370$ & - & $450-498$ \\
JM10-330 GC & $225-335$ & - & - & - \\
\hline Time Period & Early Holocene & Bølling interstadial & HE 1 & LGM \\
Age (cal years BP) & $10,080-9,840$ & $14,780-14,300$ & $17,707-16,680$ & $23,550-24,080$ \\
\hline
\end{tabular}




\begin{tabular}{|c|c|c|c|c|}
\hline Interpretation & $\begin{array}{l}\text { Northward } \\
\text { movement of the } \\
\text { Oceanographic } \\
\text { Polar Front }\end{array}$ & $\begin{array}{l}\text { Deglacial plumite } \\
\text { from rapid SBIS } \\
\text { disintegration }\end{array}$ & $\begin{array}{l}\text { Seafloor methane } \\
\text { seepage }\end{array}$ & $\begin{array}{l}\text { SBIS maximum } \\
\text { extent during LGM }\end{array}$ \\
\hline Reference & $\begin{array}{l}\text { Jansen et al., } \\
\text { 1983; Stabell, } \\
\text { 1986; Jessen et } \\
\text { al., 2010; Müller } \\
\text { and Stein, } 2014\end{array}$ & $\begin{array}{l}\text { Elverhøi et al., } \\
\text { 1995; Birgel and } \\
\text { Hass, 2004; Jessen } \\
\text { et al., 2010; Lucchi } \\
\text { et al., } 2015\end{array}$ & $\begin{array}{l}\text { Bond et al., } \\
\text { 1992; Hemming, } \\
\text { 2004; Ambrose } \\
\text { et al., 2016; } \\
\text { Stzybor and } \\
\text { Rasmussen, } \\
\text { 2017a }\end{array}$ & $\begin{array}{l}\text { Knies and Stein, } \\
\text { 1998; Vogt et al., } \\
2001 \text {; Jessen et al., } \\
2010\end{array}$ \\
\hline
\end{tabular}

In the recovered sediments, the following features were caused by the presence of methane and AOM.

Firstly, the cores retrieved from pockmarks with active flares had a strong odour of hydrogen-sulphide

(75-110 cm bsf), HH-13-203 (100-140 cm bsf) and JCR211-GC26 (70-120 cm bsf) as revealed by foraminiferal studies.

Table 4. Depth of the SMTZ in the studied cores, host sediment age, and description of magnetic 
Core ID

419

420

421

422

423

424

425

426

427

428

429

430

431

432

433

434

435

436

437
Present-day SMTZ

(cm bsf)
Host sediment age at

SMTZ position

MS

(cal ka BP)

$\begin{array}{llll}\text { HH-13-200 } & \text { 75-115 } & \text { Depleted } \\ \text { (porewater profile } & & \\ \text { available) } & & \end{array}$

HH-13-203

JM10-335GC

CAGE-14-1-GC-16

JCR211-GC26

CAGE-14-1-GC-17

HH-13-211

HH-13-212

HH-13-213

JM10-330 GC

Time frame

(cal years BP)

Interpretation
100-140

(porewater profile available)

$-$

$-$

70-120

(porewater profile available)

$13.4-12.4$

Depleted*

$-$

165-225

(inferred)

70-100

(inferred)

-

recent

$13.4-4.8$
Depleted

Depleted*

Normal

Depleted

Normal
Depleted

Depleted

no data

$10.1-4.8$

$10.3-10$ occurrence of $\mathrm{SO}_{4}{ }^{2-}$ - sediments

AOM-related dependent AOM 
Complete valves and shell fragments of juvenile and mature bivalves and gastropods in cores $\mathrm{HH}-13-$ 203 and HH-13-211 (Fig. 3) represent a chemosynthetic bivalve community (hereafter named "shell bed") that was first described in Ambrose et al. (2015). Vesicomydae bivalves dominate the species assemblage (Hansen et al., 2017). Some bivalves and ostracods were found with articulated valves, indicating they likely died in-situ. Ambrose et al. (2015) dated the shell bed to 16,7 to $17,7 \mathrm{ka}$ BP using planktic foraminifera and bivalves without MDAC overgrowth and $\delta^{13} \mathrm{C}$ values higher than $-1.6 \%$ that suggest valid ages.

445

\subsection{Stable isotope records}

\subsubsection{Oxygen isotopes}

Our records are consistent with the $\delta^{18} \mathrm{O}$ stratigraphy for planktic foraminifera from the western Svalbard margin (e.g. Elverhøi et al., 1995; Nørgaard-Pedersen et al., 2003; Rasmussen et al., 2007), the Yermak Plateau (Nørgaard-Pedersen et al., 2003) and the northern Barents Sea margin (Knies et al., 1999; 2000) during the LGM, post-LGM, and Early Holocene.

The $\delta^{18} \mathrm{O}$ values from planktic foraminifera during the LGM in the Fram Strait are typically around 4.5 to 4.8\%o (e.g. Hebbeln et al., 1994; Elverhøi et al., 1995; Nørgaard-Pedersen et al., 2003). We obtain similar values during the LGM (Figs. 2a and 4a; CAGE-14-1-GC16; HH-13-212). Termination 1 (17.8-16.7 ka $\mathrm{BP}$ ) is defined by low $\delta^{18} \mathrm{O}$ values indicative of melt-water contributions from the SBIS and can be recognised in the entire Polar North Atlantic (Hebbeln et al., 1994; Elverhøi et al., 1995; NørgaardPedersen et al., 2003).

At Vestnesa Ridge, values as low as $2.8-3 \%$ in $N$. pachyderma sin occur in post-LGM-aged sediments (Figs. 2a and 4a, HH-13-212; CAGE-14-1-GC16). We suggest the $\delta^{18} \mathrm{O}$ spike in the post-LGM sediments marks Termination 1. During the Early Holocene, $\delta^{18} \mathrm{O}$ values generally decrease. An additional, less pronounced $\delta^{18} \mathrm{O}$ spike in the Younger Dryas (Figs. 2a and 4a; HH-13-212; CAGE-14-1-GC16), signals the beginning of interglacial conditions when northwards protruding warm Atlantic water masses destabilised the ice tongues of tidewater glaciers and may have caused local meltwater pulses in the northern North Atlantic (Elverhøi et al., 1995; Rasmussen et al., 2007; Slubowska-Woldengen et al. 
A Stable oxygen isotope records

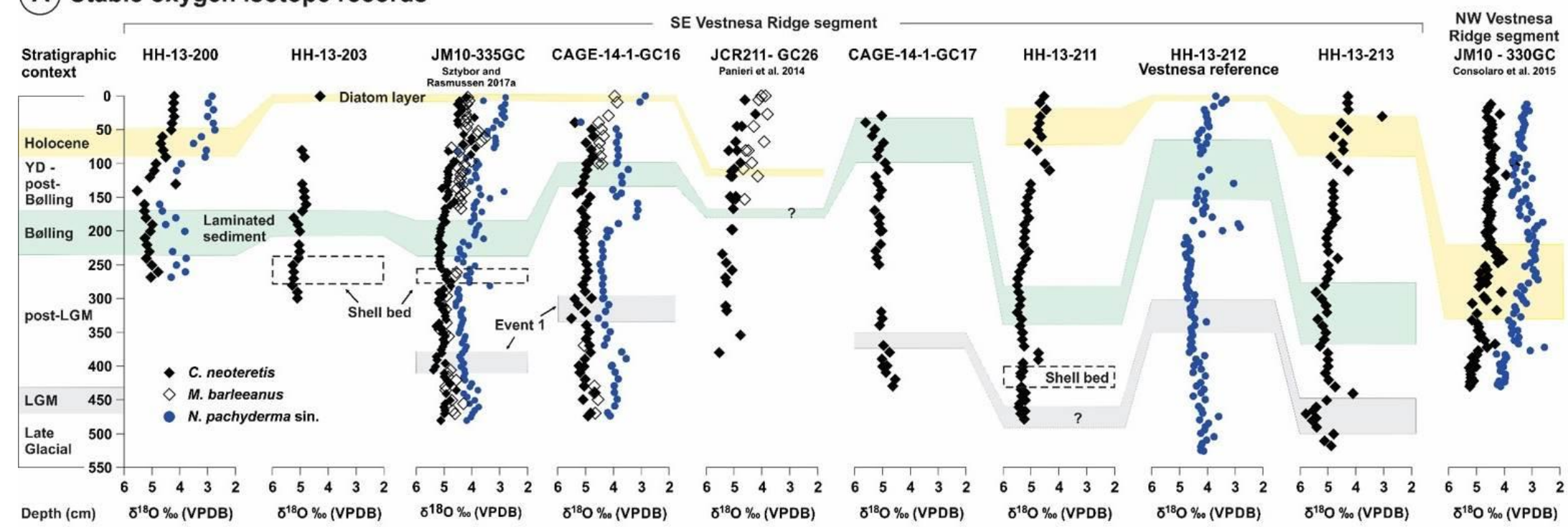

(B) Stable carbon isotope records

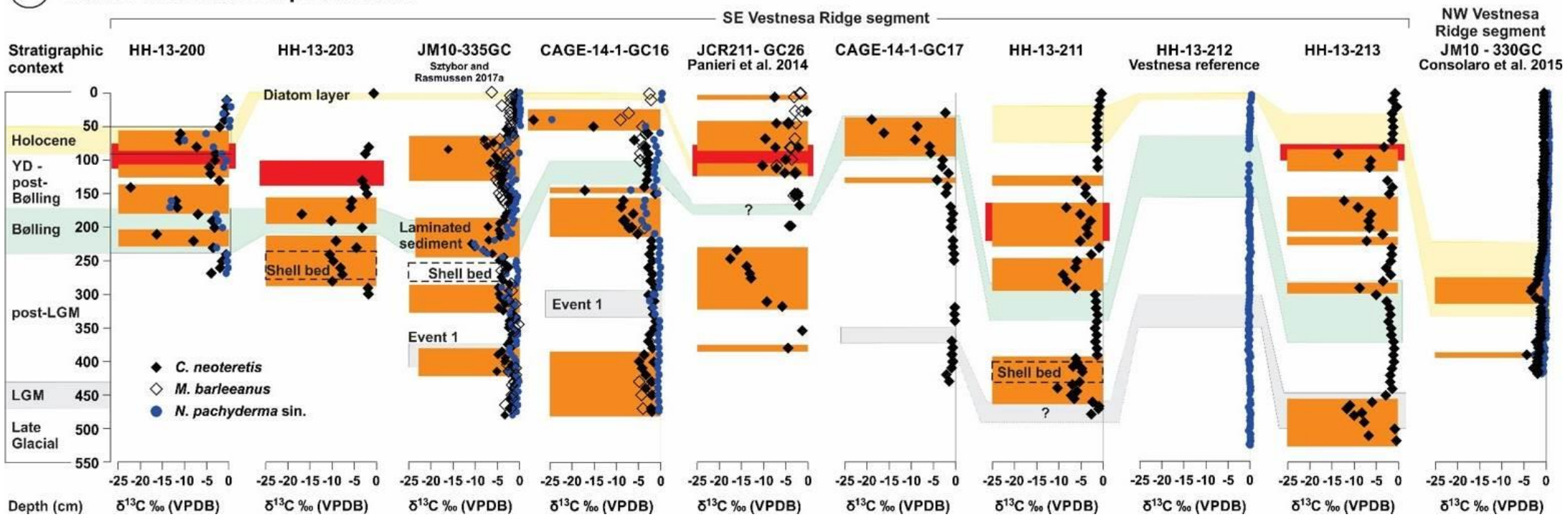


Fig. 4. $\delta^{18} \mathrm{O}(\mathrm{A})$ and $\delta^{13} \mathrm{C}(\mathrm{B})$ records of benthic (C. neoteretis; $M$. barleeanus) and planktic ( $N$. pachyderma sin) foraminifera. The Early Holocene diatom layer (9.8-10.1 ka BP), the laminated sediment deposited during the Bølling interstadial (14.3-14.8 ka BP), and near the LGM (23.5-24 ka BP) are indicated. LGM - Last Glacial Maximum. HE 1-Heinrich Event 1. YD - Younger Dryas. Orange zones are indicating the episodes of negative carbon excursions. See supplementary material S2 for the foraminiferal $\delta^{13} \mathrm{C}$ and $\delta^{18} \mathrm{O}$ values. Red boxes indicate the position of the present-day SMTZ according to table 4.

\subsubsection{Carbon isotopes}

The $\delta^{13} \mathrm{C}$ record of planktic N. pachyderma sin from core HH-13-212 (Figs. 2; 4b) ranges between 0 and $-1 \%$ and can be considered as representative of normal marine conditions, expressed as $\delta^{13} \mathrm{C}$ values between $-0,5$ and $0.5 \%$ (Knies and Stein, 1998). A $\delta^{13} \mathrm{C}$ range between 0 and $-1 \%$ o is considered representative of normal marine conditions in benthic $C$. neoteretis tests from the northern Barents Sea (0 to $-1 \%$, Wollenburg et al., 2001) and a control site from the Håkon Mosby Mud Volcano (1.15\%, Mackensen et al., 2006). For M. barleeanus, McCorkle et al. (1990) observed $\delta^{13} \mathrm{C}$ values of $2 \%$ in the Atlantic Ocean.

In contrast, the majority of the $\delta^{13} \mathrm{C}$ records of benthic and planktic foraminifera show between two and five negative $\delta^{13} \mathrm{C}$ excursions with amplitudes up to $-29 \%$ (Fig. $4 \mathrm{~b}$ ). Negative $\delta^{13} \mathrm{C}$ excursions in benthic foraminifera occur in LGM sediments (HH-13-211; -213; JM10-335GC), during HE 1 (HH-13203; -211), during and after the Bølling interstadial (HH-13-200; -203; JM10-335GC; CAGE-14-1-GC16; CAGE-14-1-GC17; HH-13-211; -213), and during the Early Holocene (HH-13-200; JCR211-GC26). In some intervals, negative $\delta^{13} \mathrm{C}$ excursions co-occur in benthic and planktic foraminifera $(\mathrm{HH}-13-200$, 60,5-220,5 cm; CAGE-14-1-GC16, 144,5-209,5 cm), while in others exclusively benthic foraminifera are ${ }^{13} \mathrm{C}$ depleted (CAGE-14-1-GC16, 359,5-439,5 cm; JM10-330GC, 255-305 cm).

Living foraminifera can incorporate ${ }^{13} \mathrm{C}$-depleted, methane-derived dissolved inorganic carbon (DIC) while metabolically active, and/or likely ingest ${ }^{13} \mathrm{C}$-depleted methanotrophic microbes, leading to 
slightly negative $\delta^{13} \mathrm{C}$ values as low as -5.6\% (Rathburn et al., 2003; Hill et al., 2004; Panieri et al., 2006; Panieri and Sen Gupta, 2008). However, values as low as $-15 \%$, as we record in planktic foraminifera, and $-29 \%$ in benthic foraminifera, cannot be explained solely by metabolic activity of the foraminifera in the presence of methane-derived DIC or foraminiferal diet. Furthermore, planktic foraminifera living in the surface water are unlikely to encounter AOM-derived DIC as benthic organisms consume most of the methane (Damm et al., 2005; Niemann et al., 2006; Reeburgh, 2007; Boetius and Wenzhöfer, 2013; Steinle et al., 2015). The strongly negative $\delta^{13} \mathrm{C}$ signatures are most likely introduced after the death of the foraminifera and burial of their tests in the sediment through the diagenetic alteration at the SMTZ. Panieri et al. (2017a) investigated the boundaries between biogenic test calcite and diagenetic overgrowth and showed that foraminiferal tests act as nucleation templates for MDAC. Schneider et al. (2017) described the visual and geochemical characteristics of foraminiferal tests experiencing diagenetic alteration during methane seepage. Such MDAC precipitation at the SMTZ cumulatively adds a second phase of ${ }^{13} \mathrm{C}$-depleted carbon on foraminiferal tests and causes negative $\delta^{13} \mathrm{C}$ values in the range of -7 to $-36 \%$ (Torres et al., 2003b; Hill et al., 2004; Millo et al., 2005; Panieri et al., 2009; Martin et al., 2010; Panieri et al., 2017a; Sztybor and Rasmussen, 2017a; 2017b; Schneider et al., 2017). We follow this interpretation and suggest that each negative $\delta^{13} \mathrm{C}$ excursion is caused by diagenetic alteration of the primary tests under the conditions of a relatively stable SMTZ at/close to the seafloor due to enhanced methane flux.

Exclusively in the reference core $\mathrm{HH}-13-212$, which is located close to active pockmarks, evidence for methane seepage and MDAC precipitation is entirely absent in planktic foraminiferal $\delta^{13} \mathrm{C}$ records (Figs. $2,4 b)$. Cores from pockmarks at the south-eastern ridge segment have the largest variability and amplitudes in $\delta^{13} \mathrm{C}$ while the north-western most core, JM10-330 GC, only shows two negative $\delta^{13} \mathrm{C}$ excursions of comparably small amplitude (Fig. 4b). The easternmost core, $\mathrm{HH}-13-200$, surprisingly shows negative $\delta^{13} \mathrm{C}$ excursions even though the core was recovered $3.5 \mathrm{~km}$ away from the nearest active pockmark (Lomvi). This may be explained by the proximity of the core-site to non-outcropping fluid flow related features, as observed in seismic data (A. Plaza-Faverola, unpublished data). 


\subsection{SMTZ migration in Holocene sediments}

523 Negative foraminiferal $\delta^{13} \mathrm{C}$ excursions are typically associated with elevated sediment $\mathrm{Ca} / \mathrm{Ti}$ and $\mathrm{Sr} / \mathrm{Ti}$ elemental ratios and with the presence of carbonate-cemented nodules in cores HH-13-200; -203; 211; and -213 (Figs. 5; 6). Elevated Ca/Ti elemental ratios identify sediment intervals with high Cacarbonate content, which can represent biogenic debris, such as foraminiferal tests or shells, or inorganic MDAC precipitates. Peaks in Ca/Ti near the base of cores HH-13-203 (Fig. 5b) and HH-13-211 (Fig. 6a) are caused by bivalves and gastropods of the shell bed as described by Ambrose et al. (2015). Large carbonate clasts in core HH-13-213 prevented XRF measurements deeper than $450 \mathrm{~cm}$ (Fig. 6b), but an initial rise in Sr and Ca content is indicative of elevated carbonate content towards the base of the core. Elevated Sr values are typical for aragonite, a common constituent of MDAC (Kastner et al., 1990) that typically precipitates when the SMTZ is close to the sediment-water interface. The $\delta^{13} \mathrm{C}$ values of the carbonate nodules range between $-36.58 \%$ and $-8.59 \%$ (supplementary material S3). Our XRD analyses (supplementary material S4) indicate that high-Mg calcite (5-20mol\% $\mathrm{MgCO}_{3}, \mathrm{Burton}$ 1993) dominates the carbonate phase in the nodules from HH-13-203 (Fig. 5b). High-Mg-calcite and aragonite comprise the carbonate phase in the nodules from $\mathrm{HH}-13-213$ (Fig. 6b). In HH-13-211 additional small fractions of low-Mg calcite (<5mol\% $\mathrm{MgCO}_{3}$, Burton 1993) and Mg-poor dolomite are present (Fig. 6a). An earlier study of the shell bed host sediments in core $\mathrm{HH}-13-203$ reveals the presence of pyrite-encrusted tube-like features, framboidal pyrite, and botryoidal aggregates of

540 acicular aragonite crystals (Ambrose et al., 2015), as well as carbonate nodules, composed of irregularly shaped 5-10 $\mu \mathrm{m}$ sized carbonate crystals cementing disseminated pyrite and detrital grains

542 (Schneider et al., 2017). Their $\delta^{13} \mathrm{C}$ signatures, mineral composition, and the co-occurrence with chemosynthetic bivalves suggest the carbonates are methane-derived and formed when the SMTZ was located at the seafloor (Aloisi et al., 2000; Bohrmann et al., 2001; Greinert et al., 2001; Naehr et al., 2007; Ambrose et al., 2015). We hence regard sediment records of MDAC, negative foraminiferal $\delta^{13} \mathrm{C}$ positions and shallow subseafloor diagenesis due to methane cycling (grey bars in Figs. 5; 6). 
(A) $\mathrm{HH}-13-200$

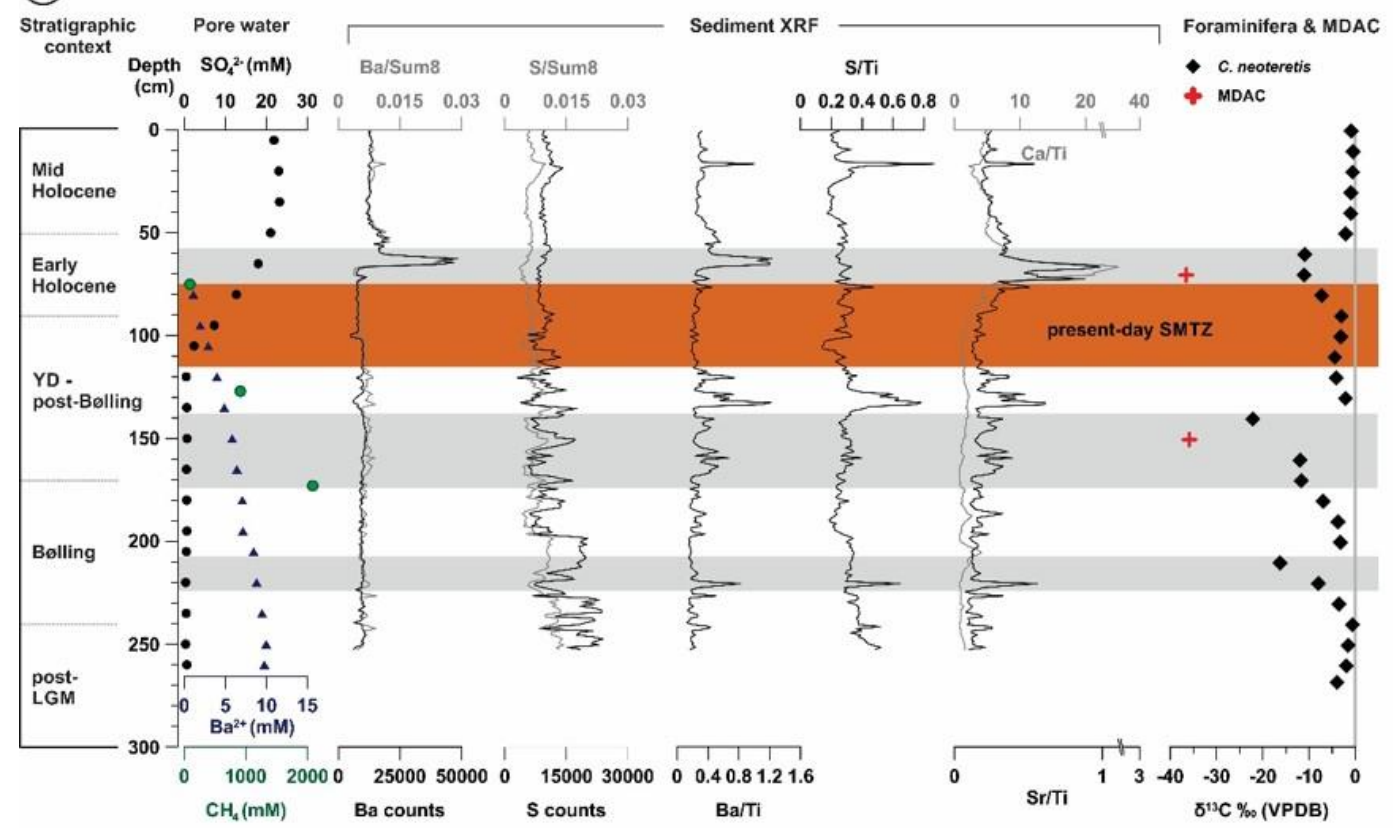

\section{(B) $\mathrm{HH}-13-203$}

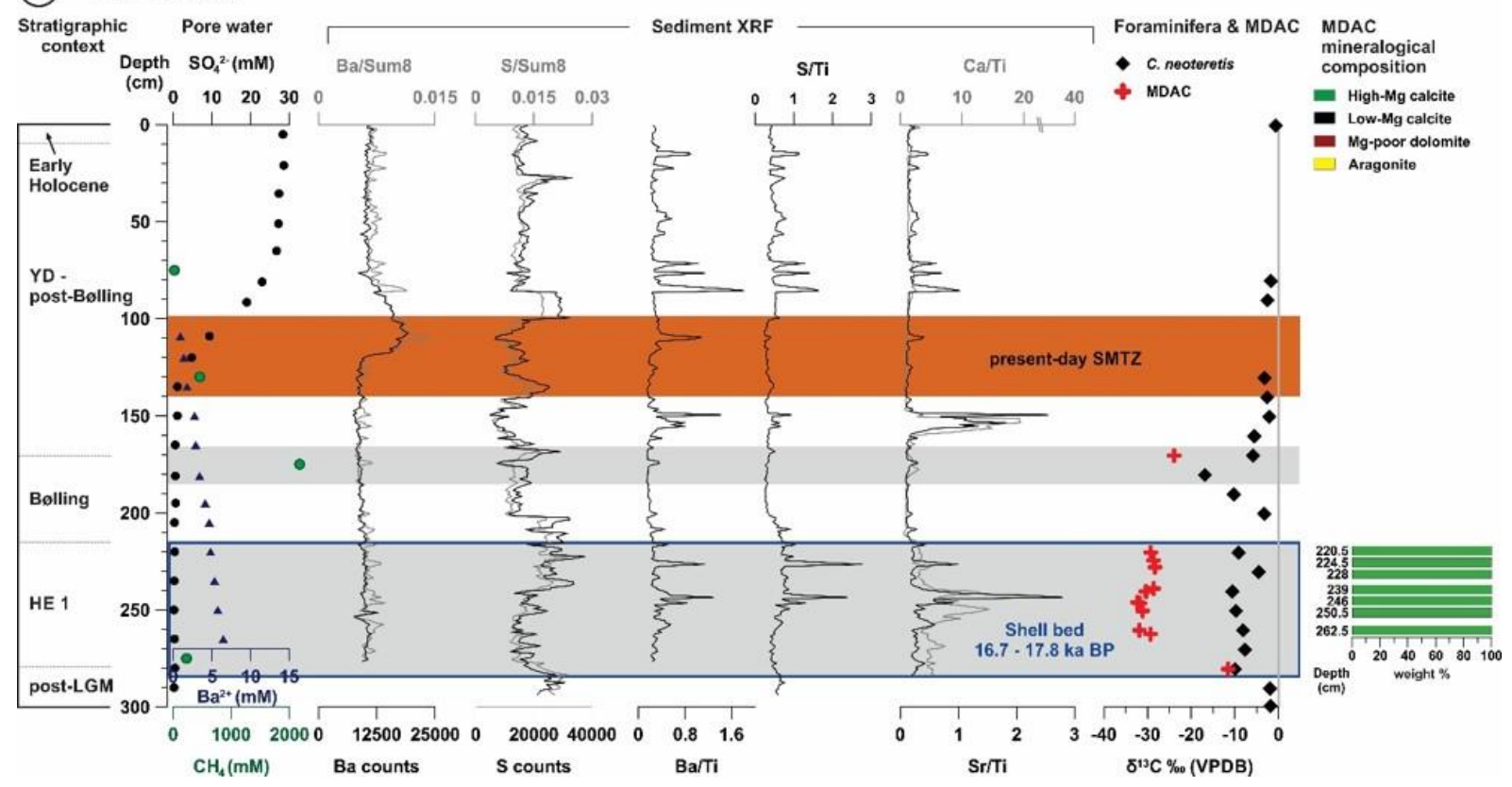

Fig. 5. Porewater data according to Hong et al. (2016), sediment elemental ratios, $\delta^{13} \mathrm{C}$ of benthic

552 foraminifera (C. neoteretis), and mineralogical composition of the MDAC nodules of (A) HH-13-200 and

553 (B) HH-13-203. The orange box indicates the present-day SMTZ as derived from porewater data. Grey bars indicate negative foraminiferal $\delta^{13} \mathrm{C}$ excursions. Position of the shell bed in $\mathrm{HH}-13-203$ according 
to Ambrose et al. (2015) (blue box). YD - Younger Dryas. HE 1 - Heinrich Event 1. Ba - Barium. S Sulphur. Ti - Titanium. Ca - Calcium. Sr-Strontium. Sum8 - sum of the eight most abundant elements in our record. Note varying scales.

A common approach to determine the present-day SMTZ position is using the mutual depletion of sulphate and methane concentrations in porewater (e.g. Jørgensen and Kasten, 2006). The presentday SMTZ in core HH-13-200 is at 75-115 cm (Tab. 4, Hong et al., 2016; host sediment age ca. 11.4-10 ka, Early Holocene, Fig. 5a), and in core HH-13-203 at 100-140 cm (Tab. 4, Hong et al., 2016; host sediment age ca. 13.4-12.4 ka, Allerød interstadial/Younger Dryas, Fig. 5b). From modelling of sulphate reduction rates, Hong et al. (2016) suggest the SMTZ has been stable for 50 ( $\mathrm{HH}-13-203)$ to 100 years (HH-13-200). Assuming persistent diffuse seepage where the SMTZ remained long enough at the same position, detectable carbonate precipitation in the sediments and on microfossils is likely to occur. In cores where porewater data are absent $(\mathrm{HH}-13-211$ and $\mathrm{HH}-13-213)$, we use barium and sulphur elemental ratios to identify the tentative SMTZ position (Fig. 6). Our approach is based on sediment and porewater Ba profiles that depend on sulphate availability as initially described by Torres et al. (1996). According to previous studies (Torres et al., 1996; Dickens, 2001; Sauer et al. 2017), Ba/Ti peaks immediately above increasing S/Ti concentrations are indicative of the SMTZ position, while double Ba-peaks can be caused by recent vertical movement of the SMTZ (Riedinger et al., 2005). In sediment XRF records of core $\mathrm{HH}-13-200$ a sharp peak in $\mathrm{Ba}$ and $\mathrm{Ba} / \mathrm{Ti}$ occurs directly above the present-day SMTZ (Fig. 5a), suggesting the precipitation of diagenetic barite. In HH-13-203, multiple Ba/Ti peaks occur above the present-day SMTZ (Fig. 5b). Sulphur counts in the sediment of both cores are low within and above the SMTZ but increase underneath (Fig. 5), and may reflect increasing amounts of authigenic pyrite (Neretin et al., 2004; Jørgensen and Kasten, 2006).

Sediment XRF ratios for $\mathrm{Ba} / \mathrm{Ti}$ and $\mathrm{S} / \mathrm{Ti}$ along with foraminifera and MDAC records from cores $\mathrm{HH}-13$ 211 and $\mathrm{HH}-13-213$ are presented in Figure 6. In $\mathrm{HH}-13-211$, a prominent $\mathrm{Ba} / \mathrm{Ti}$ peak is located immediately above a steep rise in S/Ti (Fig. 6a; 165-225 cm). In HH-13-213, the level with multiple Ba/Ti 
582 the largest barium peak and further geological evidence such as MDAC nodules, negative foraminiferal

$583 \delta^{13} \mathrm{C}$ excursions and elevated $\mathrm{Sr} / \mathrm{Ti}$ ratios at corresponding depth (Fig. 6), the tentative present-day

584 SMTZ in core HH-13-211 is at 165-185 cm (host sediment age ca. 11.9-12.3 ka, Younger Dryas, Fig. 6a)

585 while it is at 70-100 cm in core $\mathrm{HH}-13-213$ (host sediment age ca. 10.3-10 ka, Early Holocene, Fig. 6b).

\section{(A) $\mathrm{HH}-13-211$}

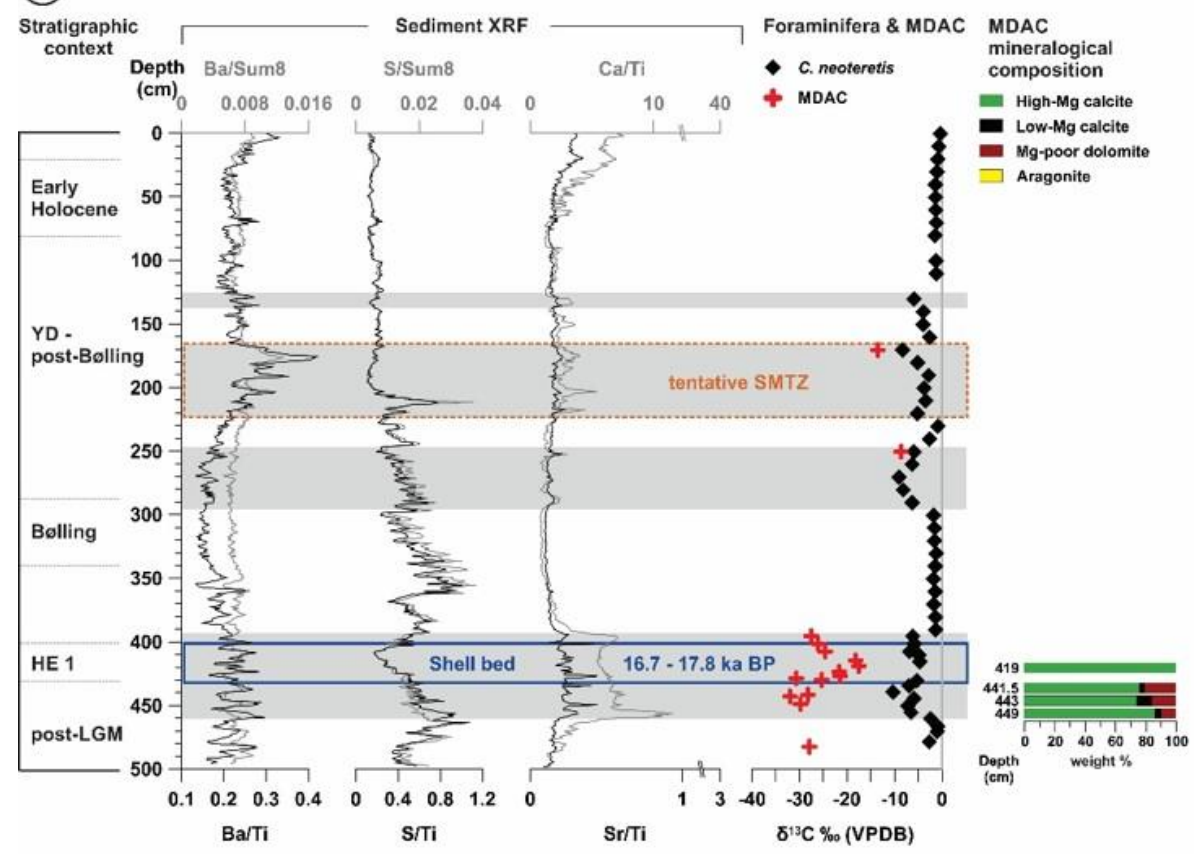

\section{(B) $\mathrm{HH}-13-213$}

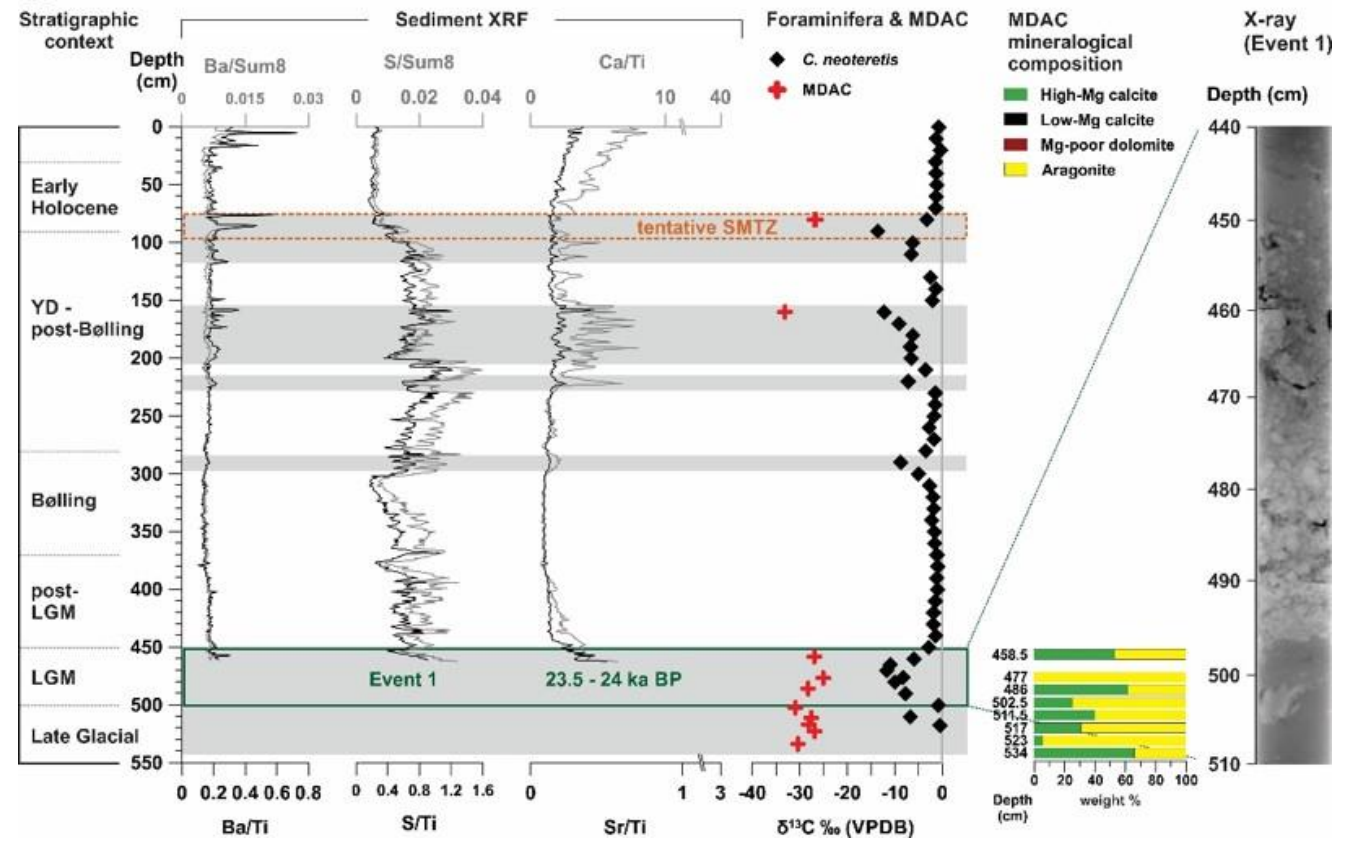


Fig. 6. Sediment elemental ratios, $\delta^{13} \mathrm{C}$ of benthic foraminifera (C. neoteretis) and mineralogical

589

590

591

592

593

594

595

596

597

598

599

600

601 composition of the MDAC nodules of (A) HH-13-211 and (B) HH-13-213. The dashed orange box indicates the tentative SMTZ. Position of the shell bed in HH-13-211 according to Ambrose et al. (2015) (blue box). Grey bars indicate negative foraminiferal $\delta^{13} \mathrm{C}$ excursions. YD - Younger Dryas. HE 1 Heinrich Event 1. Ba-Barium. S - Sulphur. Ti-Titanium. Ca - Calcium. Sr - Strontium. Sum8 - sum of the eight most common elements in our record. Note varying scales.

\subsection{Timing of past seepage episodes at Vestnesa Ridge}

Along the Vestnesa Ridge transect, 32 sediment intervals tracking subseafloor methane cycling and/or seepage episodes occur in the studied cores (Fig. 4b). We observe one major episode that occurred during the LGM at ca. 24-23.5 ka BP (Event 1) or shortly after, another significant episode coinciding with the HE 1 (17.7-16.7 ka BP), and multiple isolated episodes in up to 13.4 ka old host sediment (Fig.

7).

(A) Timing of seafloor methane seepage at Vestnesa Ridge

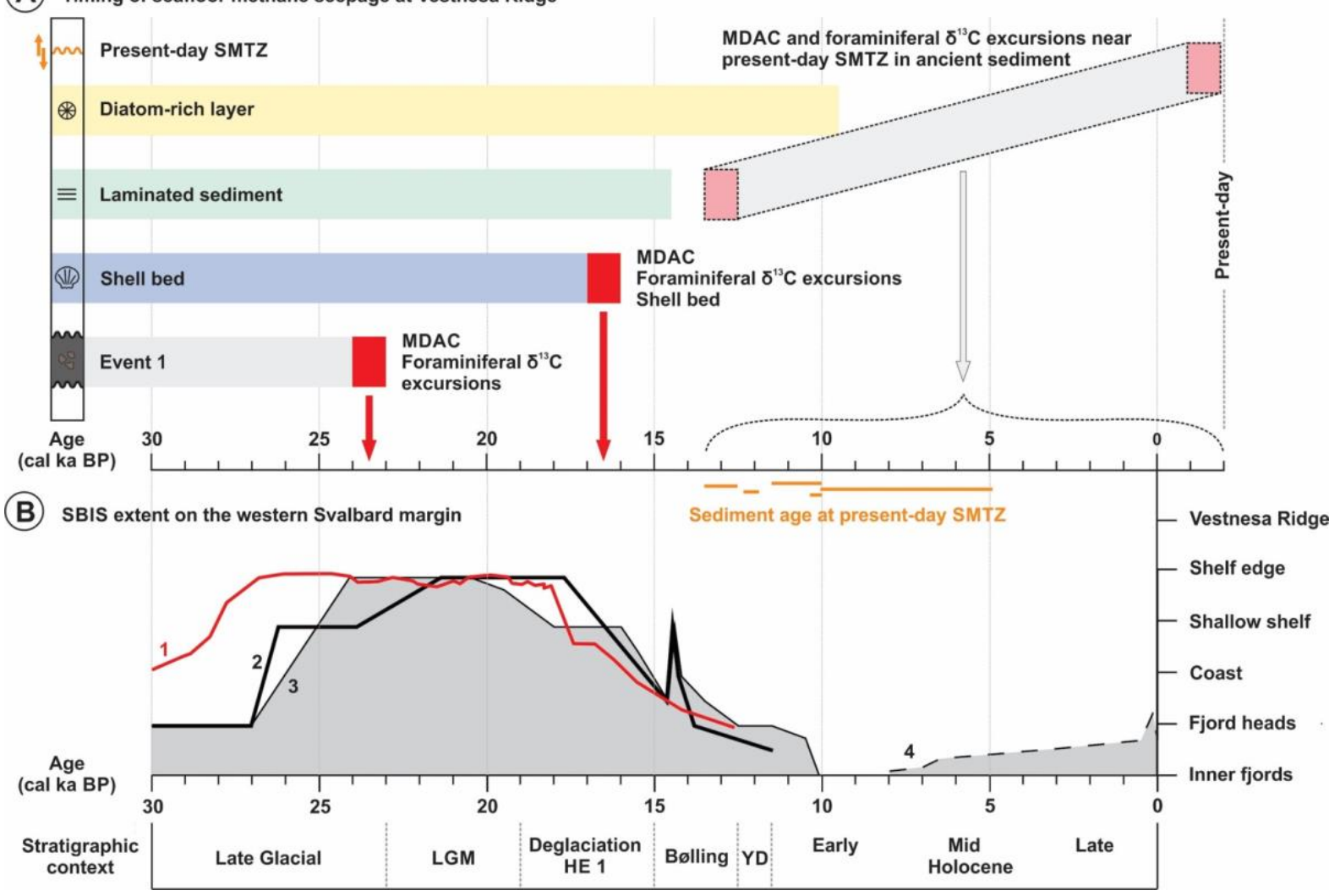


604 Fig. 7. (A) Timing of methane seepage at Vestnesa Ridge. MDAC nodules, negative $\delta^{13} \mathrm{C}$ excursions in 605 foraminiferal records, and the shell bed document main methane seepage episodes at Vestnesa Ridge 606 in sediments deposited at the LGM, during HE 1, and isolated episodes due to diagenetic methane cycling at vertically migrating SMTZs in younger sediments. (B) SBIS extent at western Svalbard during the past 30 ka. LGM - Last Glacial Maximum. HE 1 - Heinrich Event 1. YD - Younger Dryas. Modified from Jessen et al. (2010). SBIS ice extent curves are based on (1): Patton et al. (2015),

(2): Elverhøi et al. (1995), (3): Jessen et al. (2010), (4): Svendsen and Mangerud (1997).

Assessing the timing of past methane seepage is challenging since diagenetic alteration by MDAC precipitation is independent from the host sediment age. The precipitation age of aragonite-rich MDAC, which are free of detrital impurities, can be determined using U/Th chronology (Teichert et al., 2003; Bayon et al., 2009; 2013; Crémière et al., 2016b; Sauer et al., 2017). Here, available MDAC nodules are not suitable for U/Th geochronology, and therefore, only their occurrences below the present-day SMTZ can indirectly constrain the timing of subseafloor methane enrichment and methane seepage. Abundant MDAC nodules at the base of core $\mathrm{HH}-13-213$ are restricted to the Event 1 sediments (ca. 24-23.5 ka BP; Fig. 6) with high sedimentation rates (S2). We suggest the carbonate precipitation in these LGM sediments occurred syn-sedimentary or shortly post-dating the deposition. This is consistent with the aragonite dominance of the MDAC nodules that implies high methane flux and the SMTZ position very close to the seafloor. Thus, we infer that the oldest episode of subseafloor methane enrichment in this dataset occurred between the SBIS LGM shelf edge glaciation at ca. 24 ka BP (Fig. 7; Hormes et al., 2013; Patton et al., 2015 and references therein) and the deposition of the shell bed.

627 The shell bed (Ambrose et al., 2015; Sztybor and Rasmussen, 2017a) is the only directly dated paleomethane seepage episode from Vestnesa Ridge. Its age (17.7-16.7 ka BP) indicates the shell bed 
persisted for a period of approximately 1,000 years during HE 1 (Ambrose et al., 2015; Figs. 7; 8). The species composition is typical for bivalves and gastropods that lived partially burrowed at the sediment surface (Ambrose et al., 2015). Furthermore, the mineral composition of the MDAC nodules found within the shell bed in cores $\mathrm{HH}-13-203$ (Fig. 5b) and $\mathrm{HH}-12-211$ (Fig. 6a) suggests that the chemosynthetic bivalve community colonised the former sediment surface. The shell bed occurs in two different pockmarks spaced approximately $2 \mathrm{~km}$ apart, but is absent in the area between those pockmarks. The similar species composition and concurring ages suggest the shell bed represents the same biological community. During HE 1 chemosynthetic bivalves recovered from the two different pockmarks document a common methane seepage phase suggesting a regional event.

Ongoing methane seepage at Vestnesa Ridge has been under regular observation since 2008 (Hustoft et al., 2009; Bünz et al., 2012; Panieri et al., 2017b) and seems to be persistent for at least a decade. At the western Svalbard margin and Vestnesa Ridge, erosion or non-deposition throughout the Holocene exposes sediments older than 10-9 ka at the seafloor (Elverhøi et al., 1995; Howe et al., 2008) and the present-day SMTZ (in cores HH-13-200; HH-13-203 and JCR211-GC26) occurs in host sediments up to 13.4 ka old (section 4.3; Figs. 5; 6). We suggest that geological evidence for past methane seepage in post-glacial sediments, such as negative foraminiferal $\delta^{13} \mathrm{C}$ excursions, MDAC nodules, and elevated $\mathrm{Sr} / \mathrm{Ti}$ elemental ratios, do not necessarily correspond to the host sediment age. Those proxies may in reality represent the present-day SMTZ, or SMTZ shoaling in ancient host sediment due to changes in methane fluxes.

Our data do not reveal if all methane was consumed via AOM at the SMTZ, or if a fraction of the methane surpassed the SMTZ, left the seafloor sediments, and eventually entered the bottom water. Because of their diagenetic nature, sedimentary proxies indicating paleo-SMTZs may not always correspond to paleo-methane seepage, but instead may represent dynamic vertical SMTZ migration and subseafloor methane cycling in ancient host sediments.

From the Lunde and Lomvi pockmarks, high spatial heterogeneity of seepage with diffuse and focused fluid flow has been described by Panieri et al. (2017b). Thus, observations of subseafloor methane 
enrichment and SMTZ shoaling may suggest weaker, diffuse fluid flow while stronger, focused fluid flow that is currently occurring from pits within the Lunde and Lomvi pockmarks may be analogous to the fluid flow regime during the formation of the shell beds.

\subsection{Seepage drivers}

Two hypotheses compete about the governing controls on seepage timing at Vestnesa Ridge: 1) Changes in the oceanic thermal regime have the ability to drive gas hydrate dissociation (Sztybor and Rasmussen 2017a); and 2) changes in the lithospheric stress regime may result in increased tectonic activity, reactivation of pre-existing faults and fractures, and thus initiating gas migration and seafloor methane seepage (Ambrose et al., 2015; Consolaro et al., 2015; Plaza-Faverola et al., 2015).

\subsubsection{Seepage in response to bottom water temperature (BWT) increase}

During the LGM, BWTs in the Arctic Ocean and the Nordic Seas have been $2-3^{\circ} \mathrm{C}$ warmer than Holocene and modern temperatures (Cronin et al., 2012; Thornalley et al., 2015). After SBIS disintegration, the BWT along the western Svalbard margin remained warm due to northward advection of Atlantic water, and probably peaked during HE 1 and the Bølling-Allerød interstadials (Rasmussen and Thomsen, 2004; Rasmussen et al., 2007; Ślubowska-Woldengen et al., 2007; Sztybor and Rasmussen, 2017a; Consolaro et al., 2017). This is based on the abundance of warm-water benthic foraminifera and Vesicomyidae bivalves, the latter are today most abundant at low latitudes between $30^{\circ} \mathrm{S}$ and $30^{\circ} \mathrm{N}$, and nearly absent at latitudes beyond $60^{\circ}$ (Krylova and Sahling, 2010; Hansen et al., 2017). Sztybor and Rasmussen (2017a) hypothesize that Vesicomyidae may have benefited from warmer BWT at Vestnesa Ridge during HE 1 and propose that, in addition to elevated methane concentrations, warmer BWT during HE 1 may have been a controlling factor on the occurrence of the shell bed.

It is unlikely that the available heat energy from elevated BWT during the LGM was adequate to warm up the shallow sediment and dissociate even small-scale near-seafloor gas hydrate accumulations at Vestnesa Ridge, heat propagation through sediments is generally slow (Xu et al., 2001; Taylor et al., 2005; O'Connor et al., 2010; Darnell and Flemings, 2015); in fact it takes about 2000 years for a $2^{\circ} \mathrm{C}$ 
682

683

684

685

686

687

688

689

690

691

692

693

694

695

696

697

698

699

700

701

702

703

704

705

706

707

positive anomaly to raise the temperature in $100 \mathrm{~m}$ depth by $1^{\circ} \mathrm{C}$. Thus, deeper and larger gas hydrate deposits are unlikely to be immediately affected by the HE 1 BWT increase. Furthermore, chemosynthetic bivalve communities are known to colonize seeps over time scales of decades to centuries (Callender and Powell, 2000; Kiel, 2010; Bowden et al., 2013; Levin et al., 2016). Therefore, we do not support the hypothesis that BWT increase during HE 1 alone was the main reason why methane seepage occurred and chemosynthetic organisms colonised the seep.

\subsubsection{Effects of glacio-isostatic adjustment (GIA) on methane seepage}

The fact that recorded seepage episodes at Vestnesa Ridge are restricted to neither glacial nor interglacial periods suggests that the drivers controlling seepage activity are not strictly related to climatic and/or oceanographic variations, but may involve other Earth system processes. Ambrose et al. (2015) hypothesize that the occurrence of the shell bed was associated with tectonic instabilities such as faulting and fracturing leading to a 1000 years long seepage episode at Vestnesa Ridge. In contrast, Consolaro et al. (2015) suggested the combined effect of sea level rise, elevated sedimentation rate, and isostatic rebound as important factor for seepage modulations at Vestnesa Ridge.

In particular, glacio-isostatic adjustment (GIA) accompanying variations in SBIS extent emerges as an alternative explanation for SMTZ migration and seepage on Vestnesa Ridge. Glacio-isostatic adjustment is the viscoelastic response of the Earth`s surface to loading and unloading of the crust due to ice sheet dynamics, which causes two main types of stresses. Vertical stresses occur due to crustal subsidence and displacement of viscous mantle material to the periphery of the load centre during ice sheet growth (Lambeck and Chappell, 2001; Peltier, 2001; Whitehouse 2009; Lund, 2015). The horizontal flexure of the Earth's crust and increases in the pore fluid pressure can cause fault instabilities and opening of fractures (Hutri et al., 2007; Lund et al., 2011). In addition, the rebound stress (i.e. during deglaciation) can be strong enough to cause slip on faults that are close to failure due to background regional stresses (e.g. Lund et al., 2011 and references therein). 
Linear high permeability conduits, such as neotectonic faults and fractures, have long been recognised as pathways for fluid migration that is commonly initiated by changes in pore water pressure and/or increased seismicity (e.g. Milkov, 2000; Revil, 2002; Jonsson et al., 2003; Ho et al. 2010; Dupre et al., 2015; Franek et al. 2017). Additionally, a modelling study performed by Klusman and Saeed (1996) suggests gaseous hydrocarbons preferably migrate vertically as buoyant microbubbles along fault systems. For the western Svalbard continental margin, the chemical characteristics of gaseous hydrocarbons suggest vertical migration along re-activated fault systems (Knies et al., 2004). This is consistent with a study from Mau et al. (2017) who report a significant number of gas discharge sites between 74 and $79^{\circ} \mathrm{N}$ at the western Svalbard continental margin where faults in the underlying rock, such as the Hornsund Fracture Zone, intersect with the seafloor. Although Vestnesa Ridge is located a few kilometres to the west of the shelf break of the western Svalbard continental margin on oceanic crust and in 1200 to $1300 \mathrm{~m}$ water depth, GIA at the SBIS periphery could have sparked the reactivation of pre-existing tectonic lineaments at Vestnesa Ridge. During Event 1 when the SBIS reached its maximum extent, vertical and horizontal stresses of GIA may extend over a wide area and thus may have depressed the Earth crust or supported forebulge migration (Lund 2015). Such tectonic movements could have contributed to the opening of fractures and allow fluid migration and methane release during the LGM, and the last deglaciation. The opening of fluid migration pathways may have facilitated subseafloor methane enrichment that lead to shoaling of the SMTZ, shallow subseafloor diagenesis, and/or seafloor methane seepage.

Sediments along the ridge have been exposed to complex tectonism (e.g. Crane et al., 2001). PlazaFaverola et al. (2015) documented sub-seafloor faults and fractures associated with pockmarks on both the active eastern segment and the western inactive segment. Based on differences in the faulting pattern and fault orientation on the eastern compared to the western Vestnesa Ridge segment, the authors postulated that tectonic stress variations along the ridge may control seepage activity. The striking differences between the $\delta^{13} \mathrm{C}$ curves from the core on the north-western Vestnesa Ridge 


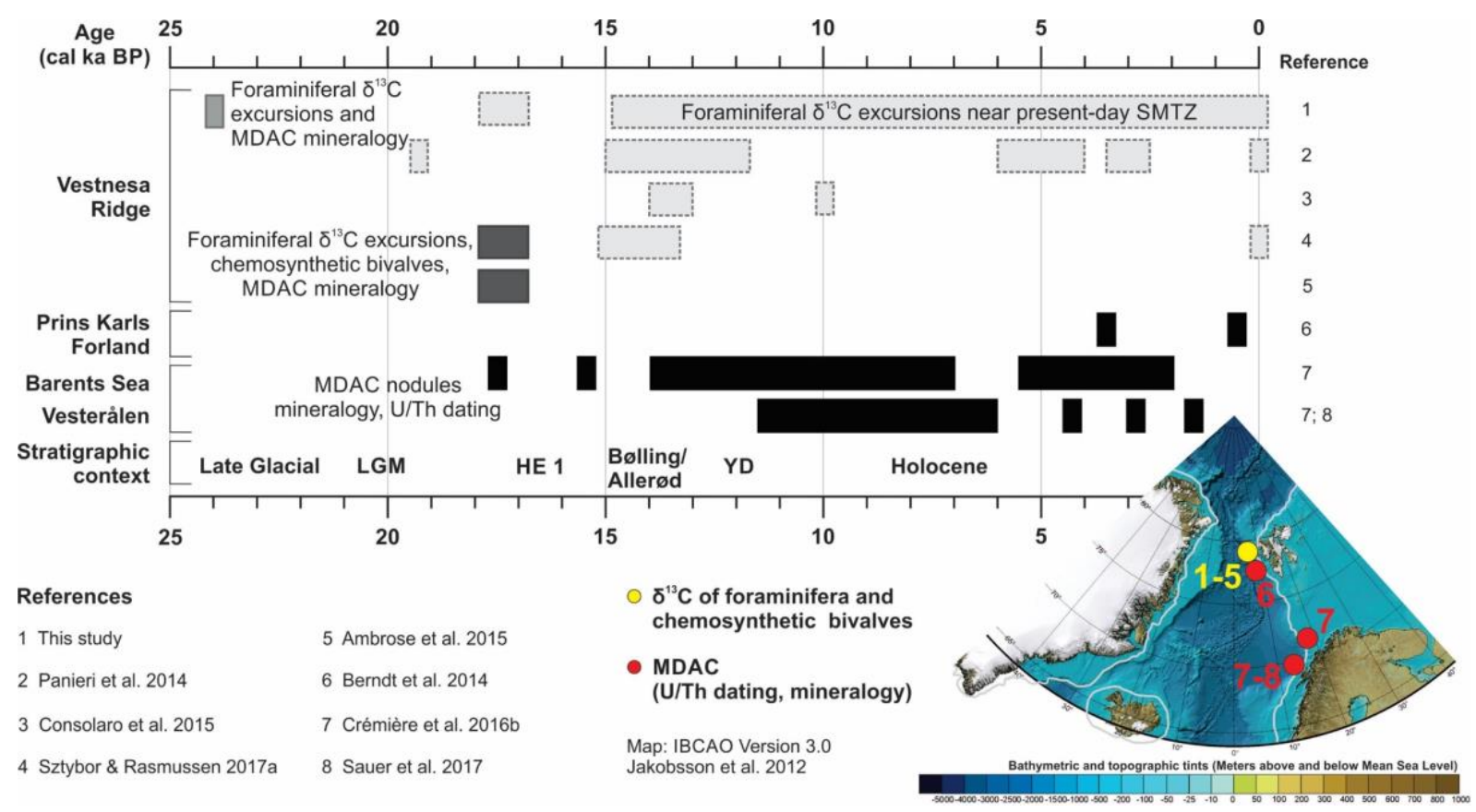

Fig. 8. Records of methane seepage since the LGM in the Nordic Seas. Light grey box - foraminiferal $\delta^{13} \mathrm{C}$ excursions and MDAC mineralogy in Event 1 sediments. Light grey boxes with dashed line foraminiferal $\delta^{13} \mathrm{C}$ excursions approximately corresponding with the present-day SMTZ position and assumed vertical SMTZ migration. Dark grey boxes - chemosynthetic bivalves of the shell bed, foraminiferal $\delta^{13} \mathrm{C}$ excursions and MDAC mineralogy. Black boxes - U/Th geochronology and mineralogy of MDAC nodules. Bathymetry from IBCAO 3.0 (Jakobsson et al., 2012). Grey line delineates the LGM extent of the SBIS, Iceland and Greenland Ice Sheets according to Patton et al. (2015).

Several lines of evidence indicate methane seepage during SBIS retreat and throughout the Holocene in the Nordic Seas (Fig. 8). Seafloor methane seepage in the south-western Barents Sea Shelf is well documented in MDAC crusts that formed between 17.5 and 2 ka BP on with the majority of U/Th dates culminating between 14 and 7 ka BP (Crémière et al., 2016b). At the Vesterålen margin offshore northern Norway, MDAC reveal methane seepage between 11.5 and 6 ka BP (Crémière et al., 2016b) 
in response to isostatic rebound, pressure release, gas migration along faults, and bottom water warming after disintegration of the Fennoscandian Ice Sheet. Thus, the subseafloor methane enrichment during the LGM and the paleo-seepage episode documented by the shell bed during HE1 are likely to be in close relationship with SBIS maximum extent and disintegration in north-western Svalbard.

After deglaciation, it takes many thousand years to reach isostatic equilibrium through delayed crustal rebound during which seismicity slowly declines. Glacio-isostatic adjustments are lasting longer than the impact of an ice sheet and thus may cause seismic and tectonic activity initiating fluid flow and seabed seepage long after an ice sheet has vanished. This is documented on Svalbard in raised shorelines throughout the Holocene (Forman et al., 1990; 2004) and earthquake activity along the Norwegian continental margin (Fjeldskaar et al., 2000; Lambeck and Chappell, 2001; Bungum et al., 2005; Lund 2015; Lee, 2009; Olesen et al., 2013). Sauer et al. (2017) obtained ages of 4.4-1.6 ka BP from seafloor MDAC crusts that were found at the Vesterålen margin offshore northern Norway. The authors suggest episodes of increased seismicity at the Lofoten-Vesterålen area are due to remaining GIA movements, that triggered earthquake activity and facilitated methane flux and MDAC precipitation. Furthermore, U/Th-dated MDAC crusts show that methane seepage occurred until 2000 years ago at the south-western Barents Sea, and has been ongoing for at least 3000 years offshore western Svalbard where MDAC also precipitated within the past 500 years (Berndt et al., 2014; Crémière et al., 2016b).

Although our dataset does not always allow differentiating between methane cycling in Early Holocene host sediment and real paleo-seepage episodes, we cannot exclude seepage during the Holocene on Vestnesa Ridge either. Some of the paleo-SMTZs in our records may indeed capture seepage episodes with similar timing as observed in MDAC in the Barents Sea and at the Norwegian continental margin. Glacial isostatic adjustment is an integral component of the Earth system and acts on geological time scales. Compelling evidence complements the hypothesis that GIA sparked tectonic activity and fault re-activation also offshore western Svalbard, may have enabled fluid migration, subseafloor methane 
enrichment, and seafloor methane seepage at Vestnesa Ridge during SBIS disintegration. Diagenetically altered foraminiferal tests, MDAC, sediment geochemical records, and chemosynthetic fauna suggests that shallow subseafloor methane cycling and seafloor methane seepage at Vestnesa Ridge may respond to long-term changes in Earth system processes (Dickens, 2003; Hong et al., 2017, Wallmann et al. 2018).

\section{Conclusions}

We have established a stratigraphic framework for the sediments along Vestnesa Ridge using the existing stratigraphic marker horizons defined for the western Svalbard margin between 76 to $80^{\circ} \mathrm{N}$. Our data are consistent with the $\delta^{18} \mathrm{O}$ stratigraphy for planktic foraminifera from the northwestern Svalbard margin during the Last Glacial Maximum (LGM), deglaciation, and Early Holocene, and thus provide an important chronological framework for stratigraphic correlation and interpretation of methane-related diagenetic processes.

Shallow subseafloor methane cycling and seafloor seepage cover the complete time span since the LGM and disintegration of the Svalbard-Barents Sea Ice Sheet (SBIS), and are documented in multiple proxies (negative foraminiferal $\delta^{13} \mathrm{C}$ excursions, MDAC nodules, elevated $\mathrm{Sr} / \mathrm{Ti}$ elemental ratios, chemosynthetic bivalves). Seafloor methane seepage occurred during the LGM (24-23.5 ka BP) and Heinrich Event 1 (HE 1, 17.7-16.7 ka BP).

Sedimentary proxies indicating paleo-SMTZs do not always correspond to seafloor methane seepage but instead may indicate shallow subseafloor methane cycling and SMTZ shoaling. Such paleo-SMTZ`s may be formed in the subsurface and do not necessarily correspond to the host sediment age. Indications of methane seepage other than during LGM, HE 1, and at the presentday SMTZ possibly represent weaker methane flux since the sediment deposition until today.

Although the influence of elevated bottom water temperatures on seafloor methane seepage cannot be excluded, we consider glacio-isostatic adjustments as most important factor controlling past and ongoing methane seepage and shallow subseafloor methane cycling on Vestnesa Ridge. 

and increased seismicity. Glacio-isostatic adjustments may have triggered the re-activation of tectonic lineaments at Vestnesa Ridge and thus could have provided fluid migration pathways.

\section{Acknowledgements}

809 This work was supported by the Research Council of Norway through its Centre of Excellence funding

810 scheme for CAGE, project number 223259, and partially by the NORCRUST project, grant

811 number 255150. Parts of the isotopic analyses were supported by the PNRA (Italian National Antarctic

812 Program) Project FORMAT. We thank the captain, crewmembers and scientific team of $R / V$ Helmer

813 Hanssen for their contribution during the research cruises CAGE-2013 and CAGE-2014. We are

814 indebted to Stefan Bünz who acquired 3D seismic data from the Vestnesa Ridge and facilitated

815 bathymetry maps for the study area. AS obtained a travel grant from the Norwegian Research School

816 in Climate Dynamics (ResClim). The manuscript benefited from editing and language correction by

817 Monica Winsborrow and Hanne-Kristin Paulsen. 